Notre Dame Law School

NDLScholarship

Journal Articles

Publications

2011

\title{
How Much Should China Pollute?
}

John C. Nagle

Notre Dame Law School, jnagle1@nd.edu

Follow this and additional works at: https://scholarship.law.nd.edu/law_faculty_scholarship

Part of the Environmental Law Commons

\section{Recommended Citation}

John C. Nagle, How Much Should China Pollute?, 12 Vt. J. Envtl. L. 591 (2010-2011).

Available at: https://scholarship.law.nd.edu/law_faculty_scholarship/349

This Article is brought to you for free and open access by the Publications at NDLScholarship. It has been accepted for inclusion in Journal Articles by an authorized administrator of NDLScholarship. For more information, please contact lawdr@nd.edu. 


\section{How Much Should China Pollute?}

\section{John Copeland Nagle*}

\section{TABLE OF CONTENTS}

Introduction 591

I. China's Right to Pollute.......................................................................596

A. Common but Differentiated Responsibilities .................................597

B. American Law's Pollution Rights..............................................604

II. China's Pollution Reduction Efforts..................................................611

A. What China Is Doing .................................................................611

B. Why China Is Trying to Reduce Its Pollution.................................615

C. The Limits on China's Pollution Control Efforts ............................620

III. Solving the Three Problems .............................................................625

A. China's Pollution Should Not Harm Itself or Others......................625

B. Achieving the Rule of Law in China ............................................626

C. The United States Should Pursue More Bilateral Agreements with China. .628

Conclusion. 632

\section{INTRODUCTION}

China is the world's worst polluter. It suffers more from air pollution than any other nation, hosting most of the world's polluted cities. ${ }^{1}$ Nearly

* John N. Matthews Professor, Notre Dame Law School. I am grateful to the Vermont Journal of Environmental Law and to the U.S.-China Partnership in Environmental Law for the opportunity to participate in the symposium on "China's Environmental Governance: Global Challenges and Comparative Solutions." I also appreciated the opportunity to present an earlier version of this article at The ISLA-Mellon Interdisciplinary Workshop on Chinese Culture and Society at Notre Dame.

1. The precise count depends on the source that you consult. See, e.g., 152 CONG. REC. S8346 (daily ed. July 27, 2006) (statement of Sen. Maria Cantwell) ("Sixteen of the world's 20 most airpolluted cities are in China."); Thomas L. Friedman, Hot, Flat, AND Crowded: Why We NeEd A Green Revolution-AND How It CAN RENEW AMERICA 404 ("Release 2.0" 2009) (quoting a Chinese official's claim that "five of the ten most polluted cities worldwide are in China"); Matthew A. Cole, Robert J.R. Elliott \& Jing Zhang, Growth, Foreign Direct Investment, and the Environment: Evidence from Chinese Cities, 51 J. REGIONAL SCI. 121, 121 (2011) ("Seventeen of the 25 most polluted cities in the world can be found in China."); Xu Yan, Green Taxation in China: A Possible Consolidated 
two-thirds of the country's 360 million urban residents suffer from unhealthy levels of air pollution. ${ }^{2}$ Anecdotal reports by visitors to China frequently refer to the alarming nature of the air pollution there. ${ }^{3}$ China's water is polluted, too. About 100 billion cubic meters of China's water supply is contaminated. ${ }^{4}$ China is also the leading emitter of greenhouse gases that contribute to climate change. ${ }^{5}$ China's carbon dioxide emissions nearly tripled between 1990 and 2008. ${ }^{6}$ And China's pollution is only expected to get worse. ${ }^{7}$ It is building unbelievable amounts of coal-fired electric power plants, ${ }^{8}$ and the number of cars in China is increasing

Transport Fuel Tax to Promote Clean Air?, 21 FordhAM ENVTL. L. REV. 295, 313 (2010) ("[S]even of the ten most air-polluted cities in the world are in China."); Elizabeth Economy, China vs. Earth: Searching for a Green Path to Grow, NATION, May 7, 2007, at 28, 28 [hereinafter Economy, China vs. Earth] ("[F]ive of the world's ten most polluted cities are in China ....").

2. See Yan, supra note 1, at 310 ("About sixty-seven percent of the urban population, or about 360 million people, is exposed to forms of air pollution that exceed the permissible standard according to the relevant data in 2004.") (citing ASIAN DEV. BANK, COUNTRY ENVIRONMENTAL ANALYSIS FOR THE PEOPLE'S REPUBLIC OF CHINA 44 (2007), available at http://www.adb.org/Documents/Produced-UnderTA/39079/39079-PRC-DPTA.pdf).

3. See, e.g., Patricia Ross McCubbin, China and Climate Change: Domestic Environmental Needs, Differentiated International Responsibilities, and Rule of Law Weaknesses, 3 ENVTL. \& ENERGY L. \& POL'Y J. 200, 213 (2008) ("The images one sees while in China are staggering: a gray, toxic cloud hovers over the entire land and blocks out the sun except for a few days a year; citizens wear masks over their faces to protect themselves from the toxic vapors; and laundry becomes blackened with soot just a few hours after being hung out to dry."); Economy, China vs. Earth, supra note 1, at 30 ("Anyone who has visited an inland Chinese city knows how terrifyingly bad the air is."); John Copeland Nagle, When the Sky Was Orange, BOOKS \& Culture, July/Aug. 2005, at 25.

4. Elizabeth C. Economy, The River Runs Black: The Environmental Challenge to CHINA's Future 1-26 (2004) [hereinafter ECONOMY, RIVER RunS BLACK] (including a chapter describing "the death of the Huai River"); Li-Wen Lin, Corporate Social Responsibility in China: Window Dressing or Structural Change?, 28 BERKELEY J. INT'L L. 64, 92 (2010) (citing THE WorLD Bank \& China State Envtl. Prot. Admin., Cost of Pollution In China 90 (2007) available at http://siteresources.worldbank.org/INTEAPREGTOPENVIRONMENT/Resources/China_Cost_of_Poll ution.pdf).

5. See Int'L Energy Agency, $\mathrm{CO}_{2}$ Emissions from Fuel Combustion: Highlights 11 (2010) [hereinafter IEA, $\mathrm{CO}_{2}$ EMISSIONS] (reporting that China accounted for twenty-two percent of global $\mathrm{CO}_{2}$ emissions in 2008, compared to nineteen percent emitted by the United States).

6. See id. at 24.

7. See id. (predicting that China's $\mathrm{CO}_{2}$ "emissions in 2030 will be almost twice current levels").

8. As Professor Vandenbergh explains:

China's emissions are increasing at a rapid rate in large part because of new construction of coal-fired electric power plants. It added electric power plants with a generating capacity of 102 gigawatts in 2006, an amount equal to all of the electric power generating capacity in France, after adding an amount equal to all of Britain the year before. On average, a new coal-fired electric plant large enough to serve a city the size of Dallas opens in China every seven to ten days. Overall, China and other developing countries are projected to account for $85 \%$ of global energy growth between 2003 and 2020. 
exponentially. China "is expected to release five times more carbon dioxide over the next twenty-five years than the Kyoto Protocol is projected to save." $"$

That pollution creates problems for three separate entities. First, it is a problem for China itself. The health of the Chinese people suffers from the polluted air that they breathe and the polluted water that they drink. "Air pollution causes the premature deaths of 750 thousand Chinese people every year." ${ }^{\prime 10}$ Just one percent of China's urban residents "breathe[] air considered healthy by the World Health Organization." " China's pollution also has a profound detrimental impact on the nation's economy. Economists suggest that China's staggering economic growth statistics would be much more modest if the economic effects of polluters are included. ${ }^{12}$ The health and economic aspects of pollution, in turn, cause domestic unrest that threatens the stability of the Chinese government. There have been numerous protests against pollution from existing or proposed facilities throughout China. ${ }^{13}$

Second, China's pollution also produces an American problem. ${ }^{14}$ Pollution emitted in China reaches the United States, sometimes at levels prohibited by the Clean Air Act. ${ }^{15}$ China is also the most common

Michael P. Vandenbergh, Climate Change: The China Problem, 81 S. CAL. L. REv. 905, 915 (2008) (citations omitted).

9. Id. (citing Patrick Symmes, The China Question: Leaping Tiger, Drowning River, OuTSIDE ONLINE, Apr. 2007, http://outside.away.com/outside/destinations/200704/yangtze-river-china-1.html).

10. Challenges and Opportunities for U.S.-China Cooperation on Climate Change: Hearing Before the Senate Foreign Relations Comm., 111th Cong. 2 (2009) [hereinafter 2009 Senate Hearing] (statement of Sen. John Kerry). Senator Kerry did not offer a source for that claim, but presumably he relied on a preliminary United Nations report that reached that conclusion. A similar report by the World Bank and China's State Environmental Protection Administration (SEPA) omitted similar premature death statistics, apparently at the behest of Chinese government officials who "feared the result would cause social unrest in China." Lin, supra note 4, at 92 (citing Joseph Kahn \& Jim Yardley, As China Roars, Pollution Reaches Deadly Extremes, N.Y. TIMES, Aug. 26, 2007, http://www.nytimes.com/2007/08/26/world/asia/26china.html).

11. Jonathan Watts, When a BiLlion Chinese Jump: How China Will SAVE MankindOR DESTROy IT 179 (2010).

12. See Lin, supra note 4, at 92 ("In September 2006[, the] State Environmental Protection Administration (SEPA) and the State Statistics Bureau issued a Green GDP report stating that in 2004 environmental pollution cost China $\$ 64$ billion, equivalent to $3.05 \%$ of GDP that year."); McCubbin, supra note 3, at 213 ("[C]urrent environmental conditions drain away more than three percent of the nation's annual GDP....").

13. See Vandenbergh, supra note 8, at 921 (describing the China problem).

14. See id. at 923-28. (describing the America problem).

15. See 152 CONG. REC. S11,025 (daily ed. Nov. 16, 2006) (statement of Sen. Lamar Alexander) ("China's air pollution is also our air pollution because air pollution both deposits locally and moves around the globe ...."); FRIEDMAN, supra note 1, at 404 (writing that EPA "reports that on some days almost 25 percent of the polluting matter in the air above Los Angeles originated in China"); Bryan Tilt, The Struggle for Sustainability in Rural China: Environmental Values and 
antagonist in American debates about climate change. Members of Congress routinely make two arguments about China as a basis for opposing federal climate change legislation or international climate change treaties. The first argument claims that the United States will lose jobs to China if we internalize the costs of emitting greenhouse gases but China does not. The second argument insists that it is unfair for China to be allowed to continue to emit greenhouse gases if the United States is obliged to cap its emissions. Moreover, many American politicians note that the environment itself will suffer if the United States reduces its emissions but China does not. Such concerns persuaded the Senate to vote ninety-seven to zero in 1997 to ratify a resolution proclaiming that "the United States should not be a signatory to any protocol" to reduce greenhouse gas emissions "unless the protocol or other agreement also mandates new specific scheduled commitments to limit or reduce greenhouse gas emissions for Developing Country Parties within the same compliance period." ${ }^{\prime 16}$ Numerous Senators pointed to the forthcoming Kyoto Protocol's treatment of China as justifying the American refusal to endorse that agreement. ${ }^{17}$ The United States never did ratify the Kyoto Protocol, and similar concerns about China continue to animate congressional opposition to a new international climate change agreement. ${ }^{18}$

CIVIL SOCIETY 67-68 (2010) (noting that scientists have traced pollution emitted in northeastern China to Oregon).

16. S. Res. 98, 105th Cong. (1997).

17. See, e.g., 143 CONG. REC. 15,784 (daily ed. July 25, 1997) (statement of Sen. Charles Hagel) (objecting to the "current negotiating strategy of binding United States and other developed nations to legally binding reductions without requiring any new or binding commitments from 130 developing nations such as China ... . The exclusion of these nations is a fatal flaw in this treaty."); id. at 15,795 (statement of Sen. Max Baucus) ("China is a growing part of the problem, it must be part of the solution."); $i d$. at 15,796 (statement of Sen. Barbara Mikulski) ("We cannot be a part of a binding international agreement that lets countries such as China . . off the hook."); id. at 15,807 (statement of Sen. Robert Byrd) ("[W]e must bring back from Kyoto some commitments that China and other large emitters will grow in a smart way.").

18. See 2009 Senate Hearing, supra note 10, at 2 (statement of Sen. John Kerry) ("[I]f America went to zero tomorrow, China has the ability to obliterate every gain we make unless it is also part of the solution."); id. at 40 (statement of Sen. Benjamin Cardin) (explaining that many constituents believe that "if the United States enacts strict standards on carbon emissions, all it's going to do is make it easier for China to have a larger penetration into the United States market because they won't impose the same strict standards, and then you're putting United States manufacturers and producers at a disadvantage in international competition"). See generally Benjamin I. PAGE \& TAO XIE, LIVING WITH THE DRAGON: How the AMERICAN Public VIEWS THE Rise OF ChInA 17 (2010) (noting American concerns about losing jobs to China); id. at 29 (citing surveys indicating that two-thirds of Americans who support an international climate change treaty do so only if the United States does not have to make a greater economic sacrifice than China); Vandenbergh, supra note 8, at 909 ("China's position on emissions contributes to the inability of the political process in the United States to pursue the national interest. China's position not only undermines the value to the United States of reducing emissions, but it also 
Third, the rest of the world suffers because of the inability of China and the United States to agree on a method for reducing their greenhouse gas emissions. Even if the rest of the world were to reach such an agreement, the failure to include China and the United States would doom the project from the start. Together, China and the United States account for forty-one percent of the world's greenhouse gas emissions. ${ }^{19}$ Left unchecked, China's emissions alone could result in many of the harms associated with climate change. ${ }^{20}$ That is why many observers believe that " $[\mathrm{t}]$ he decisions taken in Beijing, more than anywhere else, [will] determine whether humanity thrive[s] or perishe[s]."21

These three problems confirm the importance of how much China pollutes. Climate change and greenhouse gases are exceptional in many ways, but they are like traditional pollution problems in other ways. ${ }^{22}$ This article analyzes the disagreement between the United States and China from the perspective of two polluters. Part I examines China's right to pollute. According to China, the world's leading polluter and leading emitter of greenhouse gases, it has a right to emit as much as it wants in the future. China emphasizes the principle of "common but differentiated responsibilities." The Chinese argue that they do have a responsibility to help avoid the harmful consequences associated with climate change, but that their responsibility is different from that imposed on the United States and the rest of the developed world. Again, there are two parts to that argument. One part emphasizes the need for China to achieve economic

provides opponents of emissions reductions with powerful rhetorical tools."); Bill McKibben, The Great Leap: Scenes from China's Industrial Revolution, HARPER'S MAG., Dec. 1, 2005, at 51 ("More than any other argument, this idea of 'fairness' has derailed American participation in the only international agreement to do anything about [climate change]"). The concern about China taking the jobs of American workers dates from the early 1850 s, when the first Chinese immigrants arrived in the United States. See Stefan Halper, The BeiJing Consenus: How China's Authoritarian Model Will DOMINATE THE TwENTY-FIRST CENTURY 188 (2010) ("Chinese workers taking American jobs pushed down wage rates because they were willing to take almost any job for less money.").

19. IEA, $\mathrm{CO}_{2}$ EMISSIONS, supra note 5, at 9.

20. See FRIEDMAN, supra note 1, at 400 ("China's emissions and appetites will nullify everything everyone else does to save the earth ...."); Vandenbergh, supra note 8, at 908 ("China's projected emissions are so large that, when added to the greenhouse gases already in the atmosphere, Chinese emissions alone may be sufficient to trigger catastrophic climate change even if all other countries approach near-zero emissions levels.").

21. Watts, supra note 11, at xi; see also Bruce AU ET AL., Global Governance 2020, Beyond a Global DeAL: A UN+ Approach to ClimATE GOVERnANCE 26 (2011) ("China's decisions, along with those of the United States, will largely determine the shape of global climate institutions in the post-Kyoto era."); PAGE \& XIE, supra note 18, at 1 ("The future peace and prosperity of the world is likely to depend heavily on the relationship between the United States . . . and China . ...").

22. See generally John Copeland Nagle, Climate Exceptionalism, 40 ENVTL. L. 53 (2010) (exploring the similarities and differences between climate change and other air pollution problems). 
development that lifts its people out of poverty. The second part says that it is unfair for China to bear the costs of reducing pollution when the United States and other developing countries became wealthy by polluting.

Part I further explains that there is no basis in environmental law for the right to pollute as much as someone else has already polluted. The law does not conceive of the air or the water as a resource that may be polluted until it is saturated. To the contrary, American law specifically rejects the idea that clean air or water can be polluted until the pollution actually causes harm. New polluters are usually called upon to reduce their pollution more than old polluters. China's case thus finds little precedent in American environmental law, which further explains why China's reasoning has gained such little traction in the United States.

Part II considers what China actually does to reduce its pollution. To its credit, China has done much more to reduce its greenhouse gas emissions than it is legally obligated to do. It has acted from a variety of motivations, including a desire for global leadership, genuine environmental concern, fear of domestic instability, and the opportunity for economic growth. These gains are checked, though, by China's unwillingness to constrain its unprecedented economic growth and its inability to employ the law to actually control emissions.

Part III seeks to reconcile China's rhetoric and China's actions in an effort to solve the problems that China's pollution poses for China, the United States, and the rest of the world. China should ensure that its pollution does not harm its own people or the rest of the world. China should commit to abiding by the rule of law to actually enforce the environmental regulations that it has enacted, and the United States can help China in that regard. The United States and China should also collaborate, compete, and commit in an effort to address the problems caused by China's pollution.

\section{CHINA’s Right TO POLLUTE}

China insists that it has an unlimited right to pollute so long as the country is transitioning from a developing to a developed country. This section critiques that argument. First, this part will examine China's reliance on the evolving international law idea of "common but differentiated responsibilities." China repeatedly asserts that this idea supports its claimed right to pollute, but the meaning and the status of the idea are questioned by the United States and other nations. This part also questions China's continuing status as a developing country rather than a 
developed country. China possesses many characteristics of both developing and developed countries, which renders the previous dualistic paradigm unhelpful in identifying the responsibilities of newly emerging economic powers such as China.

Next, this part shows that China's claim contradicts the premises of much domestic environmental law in the United States. American environmental law prohibits pollution that is harmful to human health. Additionally, new polluters must pollute less, not more, than existing polluters, which is the opposite of China's position as a developing country. The picture is less clear if one views climate change as a problem of cleaning up existing pollution, where a variety of equitable factors point in opposite directions. Even then, responsibility for cleaning up existing pollution is not a license for new polluters to add to the problem. Nor does China's suggestion that American consumers should be responsible for China's pollution find any support in American environmental law. In sum, this section shows that China's purported right to pollute lacks support from international environmental law and contradicts American environmental law, which is why that claim has been so unsuccessful in the United States.

\section{A. Common but Differentiated Responsibilities}

China's position relies on the provision of the United Nations Framework Convention on Climate Change (UNFCCC) which states that its "[p]arties should protect the climate system ... on the basis of equity and in accordance with their common but differentiated responsibilities and respective capabilities. ${ }^{, 23}$ The UNFCCC was the first major international environmental treaty to refer to "common but differentiated responsibilities," but the idea has been traced to earlier agreements such as the 1987 Montreal ozone protocol, the 1972 Stockholm Declaration, and even the 1919 Treaty of Versailles. ${ }^{24}$ Whatever its sources, there is now "near universal acceptance of the principle of common but differentiated responsibility for global environmental change, even if differences remain

23. United Nations Framework Convention on Climate Change art. 3, princ. 1, opened for signature June 4, 1992, 31 I.L.M. 849.

24. See Albert Mumma \& David Hodas, Designing a Global Post-Kyoto Climate Change Protocol that Advances Human Development, 20 GEO. INT'L ENVTL. L. REV. 619, 629 (2008) (admitting that "the history of the principle is murky," but citing the 1972 Stockholm Declaration and the 1987 Montreal Protocol on Substances that Deplete the Ozone Layer as precedents); Christopher D. Stone, Common but Differentiated Responsibilities in International Law, 98 AM. J. INT'L. L. 276, 278 (2004) (citing the Treaty of Versailles). 
on its implications. ${ }^{.25}$ The idea continues to evolve as nations dispute both its meaning and its status under international law.

Responsibilities are "common" insofar as all nations are affected by the problem of pollution in general and climate change in particular. ${ }^{26}$ China and the United States disagree about what it means for responsibilities to be "differentiated." According to China, developing countries should not be required to control their emissions while they are in the process of emerging from economic poverty. China's reliance on "a scientific approach to development" recognizes the tradeoffs and "balances" that must be made during the development process. ${ }^{27}$ China also insists that developed nations have a responsibility to help China and other developing countries develop their own economies. ${ }^{28}$ But China's consistent position during international negotiations has been that the international community should not impose any binding emissions limits on it or any other developing country. China repeatedly cites the idea of "common but differentiated responsibilities" as supporting that position. ${ }^{29}$

China thus emphasizes other international agreements that distinguish between the responsibilities of developed countries and developing countries. The 1992 Rio Declaration - signed by China, the United States, and many other countries-states that "[t]he developed countries acknowledge the responsibility that they bear in the international pursuit of sustainable development in view of the pressures their societies place on the

25. Patricia Birnie, Alan Boyle \& CATHERine RedgWell, International LaW \& THE ENVIRONMENT 132 (3d ed. 2009). See generally Tula HonkOnEn, THE COMMON But DifFERENTIATED ReSPONSIBILITY PRINCIPLE IN Multilateral ENVIRONMENTAL AGREEMENTS: Regulatory and POLICY ASPECTS (2009) (providing extensive analysis of the development and meaning of the idea).

26. See Duncan French, Developing States and International Environmental Law: The Importance of Differentiated Responsibilities, 49 INT'L \& COMP. L.Q. 35, 45 (2000) ("States are beginning to accept that they are under an international obligation to protect and preserve their own 'internal' environment."); Mumma \& Hodas, supra note 24, at 631 ("original[ly] meaning that all nations have a duty to protect common resources"); Stone, supra note 24, at 276 (explaining that "common" means all nations are affected).

27. Dongsheng Zang, Green from Above: Climate Change, New Developmental Strategy, and Regulatory Choice in China, 45 TEX. INT'L L.J. 201, 208-09 (2009).

28. Michael Standaert \& Toshio Aritake, China to Cut Carbon Intensity 40 Percent by 2020; Premier to Attend U.N. Summit, 25 INT'L ENV'T REP. 1106, 1107, (Dec. 9, 2009) (quoting a Chinese official who said that "[i]f we get the technological and financial support from developed countries, we could possibly meet this target sooner").

29. See supra note 24-28 and accompanying text (discussing "common by differentiated responsibilities"); see, e.g., WEN JIABAO, REPORT ON THE WORK OF THE GOVERNMENT: DELIVERED AT THE Fourth SEssion of the EleVEnth National People's Congress on MarCh 5, 2011 at 4, 9, 39 (2011), available at http://online.wsj.com/public/resources/documents/2011NPCWorkReportEng.pdf ("The Chinese government and people are willing to work with the international community to respond to risks and challenges, share in development opportunities, and make new contributions to humanity's lofty causes of peace and development."). 
global environment and of the technologies and financial resources they command. ${ }^{\prime 30}$ Developed countries, says China, must accept greater responsibility for two reasons: their historic role in causing environmental degradation and their current wealth.

A related part of China's argument observes that greenhouse gases result in harmful climate change only once the atmosphere consists of a certain quantity of such gases. While traditional air pollutants dissipate from the diluting effect of the atmosphere, greenhouse gases accumulate. On this understanding, climate change is only threatening because the United States and other developed countries have emitted an amount of greenhouse gases that has substantially narrowed the capacity of the atmosphere to accommodate more gases before harm occurs.

To some extent, the United States and other developed nations accept that responsibility. During the negotiations leading to the Kyoto Protocol, the United States recognized that some kind of differentiation is justified. ${ }^{31}$ It asserted that "the common but differentiated principle required that every nation make a commitment, and the 'level and timing of each country's commitments must be commensurate with its national abilities and level of development." ${ }^{\prime 32}$ Even Senator Byrd, who coauthored the Senate resolution unanimously condemning what became the Kyoto Protocol, agreed that "each country must make unique and binding contributions of a pace and kind consistent with their industrialization." ${ }^{33}$ As one writer recalled, "The United States diplomats only wanted something - virtually anything - in the Protocol's wording that would allow the Administration to tell Congress that developing countries were 'limiting' their emissions in 'meaningful' ways. ${ }^{~}{ }^{34}$ Nothing was forthcoming, and the United States failed to approve the Kyoto Protocol because it disagreed with that instrument's implicit understanding of "differentiated" responsibilities.

The American view insists that all nations have a responsibility to control their emissions, but different nations have different responsibilities. Thus, for example, developing countries could be allowed to emit more than developed countries, or they could be given more time to control their emissions, or they could be entitled to international financial or technical

30. Rio Declaration on Environment and Development, princ. 7, adopted June 14, 1992, 31 I.L.M. 874.

31. See Stone, supra note 24 , at 280 (writing in 1999, "many senators are agreeable to subjecting developing countries to less restrictive constraints, not ruling out even an increase in emissions over the commitment period, as long as they make some commitment on paper").

32. Mumma \& Hodas, supra note 24, at 628 (quoting Under Secretary of State Timothy Wirth).

33. 143 CONG. REC. S15,802 (daily ed. July 25, 1997) (statement of Sen. Robert Byrd).

34. Paul G. Harris, Common but Differentiated Responsibility: The Kyoto Protocol and United States Policy, 7 N.Y.U. ENVTL. L.J. 27, 45 (1999). 
assistance in controlling their emissions. ${ }^{35}$ But the United States insists that developing countries do not have an unlimited right to pollute. This is especially true of countries, such as China and India, whose economies are growing rapidly with the attendant development of industries that have traditionally been responsible for substantial amounts of pollution. Under this view, the fact that responsibilities are "differentiated" does not exonerate developing nations from any responsibility at all. ${ }^{36}$

The United States questions whether the focus on past actions or the focus on current wealth justifies China's claim that it should not be subjected to binding pollution limits. China's understanding would hold twenty-first century Americans responsible for the actions of nineteenth and twentieth-century Americans who had little reason to worry that their activities were endangering future generations. ${ }^{37}$ Nor do the historical actions of the United States easily translate into a contemporary pollution license for China. Cass Sunstein, who now heads the Office of Regulatory Affairs in the Obama Administration, has asked why the victims of pollution should be asked to pay polluters to stop polluting, and why the world should pay China to persuade it to cease imposing risks on the rest of the world. ${ }^{38}$ China should not have the right to hold the rest of the world hostage by threatening to continue to emit unlimited amounts of pollution.

Likewise, the UNFCCC contains a separate provision regarding the "respective capabilities" that is distinct from the provision related to "common but differentiated responsibilities," which suggests that the two ideas are distinct. No other principle of customary international law

35. See generally French, supra note 26 (noting that possible grounds include recognition of the special needs of developing countries, an obligation to provide assistance in sustainable development, or an inducement to persuade hesitant countries to approve international environmental agreements). An example could be "differential standards, permitting grace periods in implementation, requiring flexibility in approach, and the provision of international assistance." Id. at 39; Mumma \& Hodas, supra note 24, at 631 ("Common but differentiated responsibilities can mean that developing countries have a cap, one that they can grow into and will be adequate for their sustainable development - if they are efficient and focused on renewable sources of energy."); Stone, supra note 24 at 284 (explaining three versions: nations should bargain for appropriate differential treatment, nations are instructed to choose a course of differential treatment, or poor nations should benefit at the expense of wealthier nations).

36. See Mumma \& Hodas, supra note 24, at 631 ("There is no necessary reason why common but differentiated responsibility should mean no responsibility.").

37. See Stone, supra note 24 , at 292 ("[I]t is not clear why a contemporary U.S. citizen should make amends for the overuse of the global commons during the stretch before her forebears had immigrated.").

38. See Cass R. Sunstein, The World vs. the United States and China? The Complex Climate Change Incentives of the Leading Greenhouse Gas Emitters, 55 UCLA L. REV. 1675 (2008) (discussing the different incentives the United States and China have compared to the rest of the world in joining an international agreement to control climate change). 
differentiates on the basis of wealth. "Surely," observes Christopher Stone, "the customary rules against piracy and abusing diplomats carve out no exception for the needy." ${ }^{\prime 39}$ Many citizens of China are wealthy, and many citizens of (say) Africa, India, Germany, and France are poor. If distributional considerations are what matter, it is not at all clear that the citizens of the world should pay the citizens of China to reduce their emissions. Even if the paying nations were mostly wealthy, it remains true that millions of citizens of wealthy nations are poor, and a payment from (say) the United States, the United Kingdom, Australia, and Canada to China might well hurt millions of poor people. ${ }^{40}$

The argument about "common but differentiated responsibilities" includes another practical concern. China emphasizes, and the Kyoto Protocol adopted, a bifurcated view of the world. Each country is either "developed" or "developing." China belies that simple paradigm. Like developing countries, China is poor. Its per capita income remains in the bottom half of the world. Of the 1.374 billion people in the world who live on less than $\$ 1.25$ per day, 208 million live in China. ${ }^{41}$ Much of China's population lives as if it is a third-world country. This is true both in the countryside, where the rural peasants often live in the same way that their ancestors did generations ago; and in the cities, where the unprecedented migration of people from the countryside to the cities in search of better economic opportunities has overwhelmed the ability of the cities to provide for them. China relies upon such evidence when it describes itself as "a low-income developing country." ${ }^{42}$

39. Stone, supra note 24, at 281. Professor Stone began his article with this quote from Anatole France: "the majestic equality of the laws ... forbid[s] rich and poor alike to sleep under the bridges, to beg in the streets, and to steal their bread." Id. at 276; see also Mumma \& Hodas, supra note 24, at 632 (asserting that China's position "makes poverty a defense justifying pollution"); Stone, supra note 24, at 282 (asserting that the international law duty to prevent extraterritorial pollution is not qualified by a lack of resources).

40. See Sunstein, supra note 38 , at 1682 (illustrating wealth disparities among countries as compared to the estimated impact climate change will have on them).

41. WORld Bank, POVERTy Data: A Supplement to World DEVElopment Indicators 200811 (2008).

42. Initial National Communication on Climate Change, PeOPle's Republic of ChINA, Oct. 2004, at 1; see also JIABAO, supra note 29, at 9 ("China is still in the primary stage of socialism and will remain so for a long time to come."); Bo Wang, Exploring China's Climate Change Policy from Both International and Domestic Perspectives, 16 AM. J. CHINESE STUD. 87, 99 (2009) ("[China] chooses to align with other developing countries because they share common interests in economic development and because developing countries are strategic assets in China's foreign policy."); Lisa Friedman, U.S. and China Maintain Polite Disagreement as Climate Talks Reach Final Days, ClimateWIRE, Dec. 8, 2010, http://www.eenews.net/climatewire/2010/12/08/1/ (quoting Chinese climate change negotiator Huang Huikang as describing China as "poor" and "not at the same level as the United States"). 
But like developed countries, China has one of the leading economies in the world. It is the world's leading producer of steel, producing four times as much as the United States. ${ }^{43}$ It produces nearly three times as much coal as the United States. ${ }^{44}$ It produces half of the world's cement and manufactures twenty-eight percent of the world's aluminum. ${ }^{45}$ It had the fourth largest gross domestic product in the world in 2006, just behind Japan. ${ }^{46}$ It imports more oil than every country except the United States and Japan. ${ }^{47}$ These and other statistics are frequently cited in the many popular books reporting on China's ascension to an economic powerhouse. ${ }^{48}$

So which is it? Is China a developing country or a developed country? The answer, of course, is both-or neither. There are in fact two Chinas: wealthy, urban, and industrialized Eastern China, and poorer, rural, and comparatively agrarian Western China. ${ }^{49}$ Yet the Kyoto Protocol insists that every country must be categorized as one or the other. The Protocol assigned China to the developing country list of Annex II, thus exempting it from the greenhouse gas emission reductions imposed upon developed countries and pushing the United States toward its refusal to approve the Protocol and its eventual renunciation of it.

China's history further complicates the neat division between developing and developed countries. Historically, China was as developed as the west until the beginning of the nineteenth century. "After 1800, and especially from the middle of the century, China suffered from growing economic weakness, near implosion, debilitating division, defeat,

43. See Alliance for Am. Mfg., An Assessment of EnVironmental Regulation of the STEEL INDUSTRY IN CHINA 3 (2009) (discussing China's steel production growth since 1996 when it first surpassed the U.S.).

44. See Int'L Energy Agency, Key World Statistics 15 (2008) [hereinafter IEA, STATISTICS], available at $\mathrm{http}: / /$ www.iea.org/textbase/nppdf/free/2008/key_stats_2008.pdf.

45. ASIA SOC'Y, A ROAdMAP FOR U.S-ChINA COOPERATION ON ENERGY AND Climate CHANGE 18 (2009), available at http://www.pewclimate.org/docUploads/US-China-RoadmapFeb09.pdf.

46. IEA, STATISTICS, supra note 44 , at 50,52

47. Id. at 11 .

48. See, e.g., Ted C. Fishman, China, Inc.: How the Rise of the NeXt Superpower Challenges America AND THE WORLD (2006) (discussing China's economic rise); RoB GIFFORD, CHINA RoAD: A JOURNEY INTO THE Future OF A Rising POWER (2008) (discussing the crossroads of greatness and implosion where China stands as it is poised to become the next superpower); JAMES Kynge, China Shakes the World: A Titan's Rise and Troubled Future-And the Challenge FOR AMERICA (First Mariner Books ed. 2007) (2006) (discussing China's rise to superpower status); Oded Shenkar, The Chinese Century: The Rising Chinese Economy and Its Impact on the GlobAl ECONOMY, THE BALANCE OF POWER, AND YOUR JOB (2006) ("What we are witnessing is the sustained and dramatic growth of a future world power . ...").

49. Daniel Abebe \& Jonathan S. Masur, International Agreements, Internal Heterogeneity, and Climate Change: The "Two Chinas" Problem, 50 VA. J. INT'L L. 325, 334-35 (2010). 
humiliation and occupation at the hands of foreign powers, and a progressive loss of sovereignty." ${ }^{\circ 0}$ Then, "[f]rom around 1860 there were significant examples of Chinese industrial development that were comparable with those in Japan, notably in Shanghai. But, given China's vast size, they were too limited and too scattered." ${ }^{.51}$ Industrialization, along with restoring the country's unity, was "the central task facing the PRC [(People's Republic of China)]" when it took power in 1949. ${ }^{52}$ China's industrial base grew during Mao's rule, but it really took off when Deng Xiao Ping unleashed the forces of capitalism in 1980.

The unprecedented speed of China's development since 1980 invokes another principle of international environmental law. China relies on numerous international agreements that promote "sustainable development." But China's development is not sustainable. It is not sustainable economically, and it is even less sustainable environmentally. China admits as much. ${ }^{53}$ But China insists that its right to development cannot be constrained by environmental concerns. International law principles of "sustainable" development teach otherwise. The environmental consequences of China's development would be much less severe if that development was not as rapid. So why does China need to develop so rapidly? Nothing in any international law agreement speaks to the permissible speed of development in the context of harmful consequences of that development. China answers that its development must continue at the same rapid pace because otherwise the country will be destabilized and its government will be threatened. ${ }^{54}$ But the survival of a particular government is not the concern of international norms of sustainable development. China's position seeks to conscript international environmental law to serve the parochial interests of its governing regime.

The debate between China and the United States confirms that the correct meaning of the idea of "common but differentiated responsibilities"

50. Martin JaCQues, When China Rules the World: The Rise Of THE MidDle Kingdom AND THE END OF THE WESTERN WORLD 72 (2010).

51. Id. at 97 .

52. Id. at 98 .

53. See JiABAO, supra note 29, at 9 (admitting that China's "development is not yet well balanced, coordinated or sustainable").

54. See FrIEDMAN, supra note 1, at 401 (quoting Nayan Chanda's statement that China "has to grow at a minimum of 8 percent a year or it will explode ... because it will have so much unemployment and discontent, the population will erupt"); Abebe \& Masur, supra note 49, at 326 ("China's unwillingness to join a climate change agreement is directly related to its internal political, economic, and social dynamics: the very existence of the governing regime depends on its ability to ensure social stability in Western China by guaranteeing high rates of economic growth. A climate change agreement threatens this continued growth, and thus threatens China's fragile internal balance."). 
remains contested. The status of the idea in international law remains contested, too. ${ }^{55}$ Nonetheless, the United States accepts the general idea that it has greater responsibility than developing nations in combating today's environmental challenges. What the United States denies is that developing countries have an unlimited right to pollute. Such a right would defeat even the most ambitious efforts by developed countries to reduce emissions that are associated with climate change.$^{56}$ Regardless of who is actually right, the idea of "common but differentiated responsibilities" has failed to solve any of the three problems associated with China's pollution. China still suffers from the harms of its pollution, the United States refuses to enter an international agreement that does not impose emissions restrictions on China, and the global community cannot effectively address the problems of climate change without the participation of China and the United States.

\section{B. American Law's Pollution Rights}

China's claim that it is a developing country that has a right to pollute also contradicts the lesson of American environmental law. That law is not binding on China, but it does illustrate how an advanced legal system has resolved the questions that China seeks to raise again. ${ }^{57}$ And the American experience with environmental law also explains why the United States is unwilling to accept China's contrary claims of an unlimited right to pollute. According to American environmental law, pollution is not permissible if it harms public health, new polluters must comply with more stringent pollution regulations, the equitable factors that govern the cleanup of existing pollution do not authorize additional pollution, and pollution is attributed to producers rather than consumers.

55. See French, supra note 26, at 38 (discussing United Nations Principle 7, which recognized the concept of common but differentiated responsibility, but "whether it is a legal principle or just a political guideline is still open to debate"); Harris, supra note 34, at 45 ("[Common but differentiated responsibility] has moved from being a 'soft' international legal principle ... to a nascent but increasingly robust component of international law ...."); Stone, supra note 24, at 299 ("[Common but differentiated responsibility] has not, despite occasional claims by its proponents, been elevated to the status of a customary principle of international law.").

56. French, supra note 26, at 50 ("[T]he potential of the South to cause damage to the environment is immense. It is therefore apparent that differentiation cannot simply impose additional obligations on developed States ad infinitum.").

57. Cf. Tseming Yang \& Robert V. Percival, The Emergence of Global Environmental Law, 36 ECOLOGY L.Q. 615 (2009) (describing the development of principles of environmental law that are recognized throughout the world). 


\section{Pollution May Not Endanger Human Health}

Numerous American environmental statutes emphasize the primacy of public health. The Clean Air Act (CAA) prohibits air pollution that would harm public health or welfare. It does so through EPA's establishment of National Ambient Air Quality Standards (NAAQS) that prescribe the maximum level of certain pollutants that may be present in the ambient air. According to the CAA, EPA must set the NAAQS for each pollutant at a level "to protect the public health" with "an adequate margin of safety." Primary NAAQS determine the quality of air needed to ensure public health, including the health of "sensitive" populations such as children and the elderly. Secondary NAAQS set the pollution limits needed to protect public welfare, including protection against decreased visibility, ecological harms, and property damage. EPA may not consider the cost of the pollution control measures that are needed to achieve the NAAQS. ${ }^{59}$

The Clean Water Act (CWA) takes a slightly different approach. The CWA begins by prescribing the specific technology that each category of polluters must employ to reduce their discharges into the water. Additional measures are required if that technology fails to reduce the amount of pollution to the amount that each body of water can tolerate. States decide how much pollution is tolerable based on the desired use of the water. The resulting Water Quality Standards are then translated into the Total Maximum Daily Load (TMDL) of pollutant that may be discharged into the water, and those TMDLs yield specific regulations for each source of pollution. ${ }^{60}$

The Safe Drinking Water Act (SDWA), in turn, protects the quality of waters that are or may be used for drinking water supplies. EPA must establish minimum standards to protect drinking water based on an assessment of risks and costs. States may then add to those rules by establishing secondary standards that consider other uses of the water. ${ }^{61}$

58. 42 U.S.C. $§ 7409$ (b)(1) (2006).

59. See Whitman v. Am. Trucking Ass'ns, 531 U.S. 457, 486 (2001) ("The EPA may not consider implementation costs in setting primary and secondary NAAQS under $\S 109$ (b) of the CAA."); see also David M. Driesen, Should Congress Direct the EPA to Allow Serious Harms to Public Health to Continue?: Cost-Benefit Tests and NAAQS under the Clean Air Act, 11 Tul. ENVTL. L.J. 217, 234 (1998) (defending the CAA's focus on public health).

60. See generally Summary of the Clean Water Act, U.S. EnVtl. Prot. Agency, http://www.epa.gov/lawsregs/laws/cwa.html (last updated Mar. 2, 2011) (detailing the fundamental aspects of the Clean Water Act).

61. See generally Safe Drinking Water Act, U.S. ENvTL. Prot. AgEnCY, http://water.epa.gov/lawsregs/rulesregs/sdwa/index.cfm (last updated Mar. 3, 2011) (detailing the fundamental aspects of the Safe Drinking Water Act). 
In each instance, pollution that harms public health is prohibited. There are different ways of understanding that goal and different ways of achieving it. Pollution that does not harm public health may also be prohibited because it interferes with other aspects of public welfare, or such pollution may be tolerated. But public health is always judged to be more important than economic growth.

\section{New Polluters Are Held to Higher Standards}

China's position presumes that it has a right to pollute because it has not polluted as much as other countries have during previous years. The United States Clean Air Act takes the opposite position. New polluters are required to pollute less than existing polluters. The NAAQS adopted by the CAA provide that air quality in each part of the United States must be sufficiently clean to ensure public health. The CAA further provides that new polluters may not simply move to places where air quality is already clean. Pursuant to the CAA's Prevention of Significant Deterioration (PSD) program, new sources located in areas that have already attained the NAAQS are held to heightened pollution control standards. Additionally, the CAA's new source performance standards (NSPS) were intended "to reduce pollution by having more stringent control technology incorporated into new facilities that were replacing old facilities. ${ }^{962}$ Conversely, the CAA grandfathered some existing polluters from having to comply with the law's emissions standards. ${ }^{63}$ The rationale for the distinction between new and old polluters emphasized that "new plants could be designed from the start to take pollution reduction into account," while old plants "had often been designed with little or no thought to pollution control" and thus "would frequently require expensive retrofitting" to reduce their pollution. ${ }^{64}$ That rationale, in turn, would require China to adopt more stringent pollution controls in its newly built plants than those already employed in existing facilities in other countries.

62. ARnOld W. Reitze JR., Stationary Source Air Pollution LaW 161 (2005).

63. See Bruce R. Huber, Transition Policy in Environmental Law, 35 HARV. EnVTL. L. ReV. 91, 93 (describing the CAA's grandfathering provisions).

64. Bruce A. Ackerman \& William T. Hassler, Clean Coal/Dirty Air: Or How the Clean Air Act Became a Multibillion-Dollar Bail-Out for High-Sulfur Coal Producers And What Should Be Done About It 11 (1981); see also Robert N. Stavins, Vintage-Differentiated Environmental Regulation, 25 STAN. ENVTL. L.J. 29, 30 (2006) (“[I]t is frequently more cost-effectivein the short term - to introduce new pollution-abatement technologies at the time that new plants are constructed than to retrofit older facilities with such technologies" and "it seems more fair to avoid changing the rules of the game in midstream, and hence to apply new standards only to new plants."). 


\section{Equitable Factors to Clean up Past Pollution}

Pollution may present a remedial problem as well as a preventative one. China often argues that climate change is such a remedial problem because the harms of climate change result from two centuries of greenhouse gas emissions by developed countries. Those gases remain in the atmosphere and count toward the maximum parts per million beyond which the harms of climate change materialize. China and other developing countries thus object that they are not allowed to emit enough pollutants during their phase of economic development because of the historical actions of the United States and other developed countries. China thus insists on its fair share of pollution.

The Comprehensive Environmental Response, Compensation, and Liability Act (CERCLA) provides the best American environmental law model for allocating cleanup responsibility among polluters. ${ }^{65}$ Like the emitters of greenhouse gases, CERCLA "defendants can vary widely in terms of their degree of causal responsibility and the culpability of their actions. ${ }^{966}$ CERCLA is also equipped to consider the effects of pollution from a variety of actors in different places over extended periods of time. Generally, CERCLA's liability scheme deems anyone who was associated with the property during the disposal of hazardous wastes to be a "responsible party" who must help pay for the cleanup of those wastes. ${ }^{67}$ Liability is often joint and several. ${ }^{68}$

CERCLA's lesson for climate change comes when the statute seeks to allocate liability among multiple parties who have already been judged to be jointly and severally liable. The statute itself does not specify the proper method of allocating costs, so the courts have looked at the factors that Representative Al Gore listed during the congressional debate over CERCLA. The "Gore factors" include the amount of waste, its degree of toxicity, the degree of the party's involvement in handling the waste, the

65. See generally Comprehensive Environmental Response, Compensation, and Liability Act (CERCLA), 42 U.S.C. $\$ \S 9601-9675$ (2002) (providing the full text of the statute); CERCLA Overview, U.S. ENVTL. PROTECTION AGENCY, http://www.epa.gov/superfund/policy/cercla.htm (last updated Mar. $25,2011)$ (providing information and resources on CERCLA, or Superfund).

66. Daniel A. Farber, Apportioning Climate Change Costs, 26 UCLA J. ENVTL. L. \& POL'Y 21, $48(2007 / 2008)$.

67. 42 U.S.C. $\$ 9607$ (a) (2006).

68. Liability used to be almost always joint and several, but the Supreme Court in Burlington Northern v. United States, 129 S. Ct. 1870, 1881-84 (2009), recently held that there are more instances in which joint and several liability is inappropriate than the lower courts had previously thought. 
party's degree of care, and the degree of cooperation with government authorities to prevent environmental harm. ${ }^{69}$

Consider how these factors could be applied to allocate the costs of climate change. China emphasizes that the United States has emitted far more greenhouse gases during the past two centuries. The degree of toxicity of greenhouse gases varies widely, with the more common carbon dioxide having a lesser effect than methane and hexafluoroethane. China releases more methane than the United States because of its abundant rice paddies. ${ }^{70}$ The degree of the parties' involvement in the emissions can be judged in different ways. From one perspective, both the United States and China have actively participated in their respective emissions. The United States could argue that its government is less involved in current emissions than China's more centralized government, but international law holds each country's government responsible for what happens within its jurisdiction. The degree of care was historically modest for both the United States and China, and while the United States has a more established pollution control system now, China is actually making notable strides in its own emissions reductions efforts. ${ }^{71}$ The degree of cooperation with government authorities to prevent environmental harm is also difficult to apply in this context since we are considering both the Chinese and the American governments themselves. Perhaps the appropriate measurement is the extent the countries have worked within the international climate change framework, which favors China because only the United States failed to ratify the Kyoto Protocol. Overall, the "Gore factors" suggest that the United States bears a greater responsibility than China for the presence of greenhouse gases in the atmosphere.

The CERCLA allocation experience also illustrates the threshold choice between using precise formulas or imprecise lists of relevant factors when deciding who has to pay to cleanup pollution. As Dan Farber explains:

One key lesson of CERCLA is that cost apportionment involves complex determinations involving multiple social

69. See S. Comm. On Env'T \& Pub. Works, 97Th Cong., A Legislative History of the COMPREHENSIVE ENVIRONMENTAL Response, COMPENSATION, AND Liability ACT OF 1980 (SuPERfund), PuB. L. 96-510 at 440 (Comm. Print 1983). For illustrations of how the courts apply the Gore factors, see, e.g., Control Data Corp. v. SCSC Corp., 53 F.3d 930, 935-36 (8th Cir. 1995); B.F. Goodrich Co. v. Murtha, 958 F.2d 1192, 1206 (2d Cir. 1992); United States v. A \& F Materials Co., 578 F. Supp. 1249, 1256-57 (S.D. Ill. 1984).

70. See Sarah Graham, Rice Paddy Methane Emissions Depend on Crops' Success, SCI. AM., Aug. 20, 2002, http://www.scientificamerican.com/article.cfm?id=rice-paddy-methane-emissi (explaining that the anoxic conditions of rice paddy soils are ideal for methane-producing microbes).

71. See infra Part II (discussing China's efforts). 
norms. In the CERCLA context, courts have never articulated a formula for how to make apportionments between responsible parties, settling instead for open-ended lists of relevant factors combined with trial court discretion. Given the much greater scale of the climate change problem, we may not be content with such ad hoc treatment. Rather, we may want to settle on some relatively mechanical formula for apportionment. The CERCLA experience suggests that no single formula is likely to appear uniquely desirable. Instead, given the complexities involved, we will have to choose among competing formulas that each have some appeal. The choice will probably involve some degree of imprecision. But, as demonstrated by CERCLA, a fairly imprecise approach to apportionment can be tolerable, so long as the relevant factors are at least taken into account. ${ }^{72}$

Yet the CERCLA example is not as helpful to China as it may hope. The purpose of CERCLA is to cleanup existing pollution, and CERCLA's allocation scheme governs who has to pay to cleanup that pollution. That model would be appropriate if there were a way to remove greenhouse gases from the atmosphere once they had been emitted. What China argues, though, is that it has a right to emit new pollution. It wants other nations to stop polluting so it can pollute instead. That is not the problem that CERCLA addresses, and there are no examples of CERCLA being used to force one party to cleanup a site so that another party can pollute it afterward.

\section{Pollution Is Attributed to Producers, Not Consumers}

China often says that the pollution emitted within its borders should be counted toward the United States and other developing countries whose consumers purchase the products that are made in China. This is not a persuasive argument for many Americans. ${ }^{73}$ Nor does it fit with American environmental law, which in most instances holds producers responsible for the pollution that they release, rather than the consumers of the products made by those polluters.

72. Farber, supra note 66, at 51.

73. See 2009 Senate Hearing, supra note 10, at 5 (statement of Sen. Richard Lugar) (objecting to "counterproductive policy demands, such as having consumers in the West pay for the carbon content of products they buy from China"). 
The Clean Air Act (CAA), for example, regulates industrial factories, energy producers, car manufacturers, and other producers whose activities result in pollution. By contrast, the CAA does not regulate consumers, energy users, and drivers. Such individuals may bear the cost of pollution regulation through increased prices, but they are not the subject of the CAA's regulations. Likewise, CERCLA's broad categories of responsible parties who must pay to clean up hazardous wastes includes the owners of contaminated land, those who owned the land or operated the facility when wastes were disposed there, those who generated the wastes, and those who shipped the wastes to the site. ${ }^{74}$ CERCLA does not hold the consumers of any of those products responsible for the costs of the cleanup. In fact, one provision of CERCLA specifically exempts "consumer products in consumer use. $\$ 75$

Michael Vandenbergh has questioned the emphasis on regulating large sources of pollution when individuals are producing a growing proportion of pollution. ${ }^{76}$ The premise of Vandenbergh's work, though, is that the CAA, the CWA, and other environmental statutes have already achieved great reductions in pollution. Individual actions thus constitute a relatively larger share of pollution than was the case before the federal government began regulating larger polluters. China is not at that stage of its legal development yet. Moreover, the concern about pollution from individuals focuses on the polluting activities of those individuals, not on their consumption habits. There may be an equitable argument for holding consumers responsible for the pollution that resulted from the products that they purchase, but so far that argument lacks significant precedent in domestic or international environmental law.

China is exporting its effects on climate change, too. It is building dams throughout the world, prompting complaints about the indiscriminate devastation of local ecosystems and the displacement of local populations. ${ }^{77}$

74. 42 U.S.C. § 9607(a) (2006).

75. See Patricia Reid, Legislative Reform: Interpretation of the Consumer Products Exception in the Definition of "Facility" Under CERCLA, 21 J. LEGIS. 141, 141 (1995) (discussing the consumer products exception under CERCLA).

76. Michael P. Vandenbergh \& Anne C. Steinemann, The Carbon-Neutral Individual, 82 N.Y.U. L. REV. 1673 (2007); Michael P. Vandenbergh, From Smokestack to SUV: The Individual as Regulated Entity in the New Era of Environmental Law, 57 VAND. L. REV. 515, 529-33 (2004).

77. See CONG.-Exec. COMM'N ON ChInA, 111Th CONG., ANNUAL RePort 31-32 (2010) [hereinafter CEC ANNUAL REPORT] ("Hydroelectric dam construction has been accompanied by lack of attention to environmental impact assessment processes mandated by law, and by reports of the infringement upon the fundamental rights of local populations."). 
It is "the largest importer of illegally logged timber in the world." ${ }^{, 78}$ Indeed, China's "demand for natural resources" is "depleting the world's stock of them." ${ }^{, 79}$ China does not mention those activities when it suggests that resource consumers should be held responsible for pollution as well as resource polluters.

\section{CHINA's POLLUTION REDUCTION EFFORTS}

China has undertaken an aggressive campaign to mitigate and adapt to climate change despite its lack of international obligations to do so. This is surprising to many in the United States who view China as unconcerned about its growing pollution. This part begins with an outline of the steps that China is taking toward reducing its emissions. This part then considers why China is taking those actions, and the obstacles to its success. ${ }^{80}$

\section{A. What China Is Doing}

China's environmental degradation is not new. China has a historical legacy of environmental abuse that worsened in the years after the Communist revolution in $1949 .{ }^{81}$ Moreover, China long relied on "moral suasion" instead of environmental laws. ${ }^{82}$ Since China began its economic development in 1980, it has enacted numerous laws designed to reduce pollution and improve environmental quality. Most of the laws are the product of the past fifteen years, when the environmental consequences of China's economic growth became so noticeable. One recent survey counted

78. 2009 Senate Hearing, supra note 10, at 14 (statement of Elizabeth Economy, C.V. Starr Senior Fellow and Dir. for Asia Studies, Council on Foreign Relations) ("[China] is contributing to rampant deforestation in places as far flung as Cambodia, Mynamar, Mozambique, Russia, and Indonesia. Even as China is undertaking positive climate mitigation efforts with its forest program within its own borders, it is contributing to the opposite in many countries abroad.").

79. JACQUES, supra note 50, at 187.

80. See 2009 Senate Hearing, supra note 10, at 6 (statement of Kenneth Lieberthal, Visiting Fellow in Foreign Policy, Brookings Inst.) ("Most Americans seem to believe that China is . . ignoring its carbon emissions while pursuing all-out economic growth.").

81. See ECONOMY, River Runs Black, supra note 4, at 17 (observing that China experienced centuries of "the plundering of forest and mineral resources, poorly conceived river diversion and water management projects, and intensive farming that degraded the land"); id. at 27-57 (including a chapter entitled "A Legacy of Exploitation"); MARK D. Elvin, THE RETREAT of THE ELEPHANTS: AN ENVIRONMENTAL HISTORY OF CHINA (2004) (providing an overview of the environmental history of China).

82. See ECONOmy, River Runs Black, supra note 4, at 17 ("China's leaders from the emperors to Mao Zedong relied on a highly personal system."). 
thirty-three major environmental laws that China enacted between 1979 and $2004 .{ }^{83}$

The next milestone in China's environmental development occurred in June 2007, when the National Development and Reform Commission published "China's National Climate Change Programme." ${ }^{84}$ That document describes "China's Basic National Circumstances of Climate Change" as including "inferior climatic conditions and severe natural disasters," "vulnerable ecosystems," a "coal-dominated energy mix," a "huge population," and a "relatively low level of economic development." It then states that China's climate change efforts will be guided by the "Scientific Approach of Development," the construction of a "socialist harmonious society," the "fundamental national policy of resources conservation and environmental protection," "economic development," energy conservation, and international cooperation. ${ }^{86}$ Next it recites several governing principles, including "sustainable development," "common but differentiated responsibilities," and pursuing "both mitigation and adaptation." ${ }^{\text {"87 }}$ The strategy's mitigation measures include "restructuring the economy, promoting technology advancement and improving energy efficiency;" "optimizing energy mix by developing low-carbon and renewable energy;" "launching national wide tree-planting and afforestation campaign and enhancing ecology restoration and protection;" "effectively controlling the growth rate of population through family planning;" "further improving institutions and mechanisms;" "attaching great importance to climate change research and capacity building;" and "strengthening education, training and public awareness on climate change." 88

China has produced annual updates on its efforts to implement its climate change strategy. ${ }^{89}$ It has agreed to reduce its carbon intensity by forty to forty-five percent by 2020 from 2005 levels. ${ }^{90}$ It instituted the Provincial Programme for Climate Change Mitigation \& Adaption in June

83. See Srini Sitaraman, Regulating the Belching Dragon: Rule of Law, Politics of Enforcement, and Pollution Prevention in Post-Mao Industrial China, 18 COLO. J. INT'L ENVTL. L. \& POL'Y 267, 296-97 (2007) (outlining environmental laws passed by China from 1979 to 2004).

84. NAT'L Dev. \& Reform Comm'N, China's National Climate Change Programme (2007) [hereinafter NDRC, CHINA'S PROGRAMME], available at www.ccchina.gov.cn/WebSite/ CCChina/UpFile/File188.pdf.

85. Id. at $14-16$.

86. Id. at 23 .

87. Id. at $24-25$.

88. Id. at 7-13.

89. See, e.g., NAT'L DEV. \& REFORM COMM'N, CHINA'S POLICIES AND ACTIONS FOR Addressing Climate Change: The Progress Report 2009 (Nov. 2009) (describing the latest progress that China has achieved in addressing climate change since 2008).

90. Standaert \& Aritake, supra note 28 , at 1106. 
2008. ${ }^{91}$ China's almost thirty-seven mile per gallon average fuel economy standard for new vehicles is more stringent than the comparable American requirement. $^{92}$

China has particularly sought to increase its use of renewable energy. The Renewable Energy Law of 2005 requires that ten percent of China's electricity be produced by renewable energy by $2020 .{ }^{93}$ The Medium and Long-Term Development Plan for Renewable Energy of 2007 raised that target to ten percent by 2010 and fifteen percent by 2020, and set targets of 30 gigawatts $(\mathrm{GW})$ of wind power, $300 \mathrm{GW}$ of hydropower, and $1.8 \mathrm{GW}$ of solar photovoltaic power by $2020 .{ }^{94}$ The Chinese government has pursued these goals by providing extensive subsidies for the development of wind, solar, hydroelectric, and nuclear energy technologies. Yet China is more likely to use a "stick" instead of a "carrot" to encourage the development of renewable energy. The government "mandate[es] both the production and consumption of renewable energy," "uses feed-in tariffs," and "dictates prices to electric grid operators, who are required, by law, to connect renewable energy sites to the provincial and national electricity grids. ${ }^{~} 95$

China has also received millions of dollars from the Clean Development Mechanism (CDM) established by the Kyoto Protocol. China accounts for over one-third of the approved CDM projects, and fifty-five percent of the credits earned by those projects. ${ }^{96}$ As of April 2009, there were more than 500 registered CDM projects located in China, and another 1500 have been approved by the Chinese government pending approval by

91. Wang, supra note 42 , at 90 .

92. See McCubbin, supra note 3, at 217 (stating that China's average fuel economy for new vehicles is much more aggressive than in the United States).

93. Rob atkinson et Al., Breakthrough Inst. \& Info. TeCh. \& InNOvation Found., Rising Tigers SLEEPING GiANT: ASIAN NATIONS SET to DOMINATE THE ClEAN ENERGy RACE By OUTINVESTING THE UNITED STATES 67 (2009), available at http://www.thebreakthrough.org/blog/ Rising Tigers.pdf; see also Joel B. Eisen, China's Renewable Energy Law: A Platform for Green Leadership?, 35 WM. \& MARY ENVTL. L. \& POL'Y REV. 1, 27 (2010) (explaining that in implementing the Renewable Energy Law, China "set a goal of meeting ten percent of China's primary energy consumption with renewable energy by 2010 , and fifteen percent by 2020 ").

94. Id.

95. Pol'y \& Global AfFairs Div., Comm. ON U.S.-China COOPERATION ON EleC. From

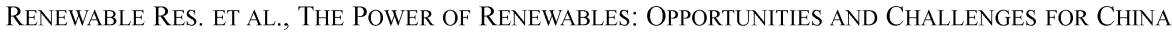
AND the United States 126 (2010) (National Academies Press 2010) [hereinafter CoMm. ON U.S.CHINA COOPERATION].

96. See CERs [(Clean Energy Reductions)] Issued by Host Party, UNITED NATIONS FrameWORK CONVENTION ON Climate Change, http://cdm.unfccc.int/Statistics/Issuance/CERsIssuedByHostPartyPieChart.html (last visited Apr. 12, 2011) (displaying CERs issued by host parties); Registered Project Activities by Host Party, UNITED NATIONS FRAMEWORK CONVENTION ON Climate Change, http://cdm.unfccc.int/Statistics/Registration/NumOfRegisteredProjByHostPartiesPieChart.html (last visited Apr. 12, 2011) (displaying the number of registered projects). 
the CDM board. ${ }^{97}$ They included improvements to industrial facilities, methane recovery from landfills, power production from biomass, the construction of wind farms, and especially the construction of hydroelectric plants. $^{98}$

Most recently, the government's Twelfth Five-Year Plan suggested that China is preparing to address its pollution more vigorously than it has before. In a speech to the National People's Congress on March 5, 2011, Premier Wen Jiabao boasted that "we made genuine progress in energy conservation, emissions reduction, ecological improvement and environmental protection," citing new greenhouse gas policies, the development of clean energy, the decommissioning of more polluting facilities, and reduced energy intensity. ${ }^{99}$ But, he added, China needs to do more, again specifically citing the need to "strengthen energy conservation, environmental protection and ecological development, and activity response to climate change." 100 Soon after his speech, Wen proclaimed in an internet chat that "[w]e must not any longer sacrifice the environment for the sake of rapid growth and reckless roll-outs, as that would result in unsustainable growth featuring industrial overcapacity and intensive resource consumption."101 Zhou Shengxian, China's environment minister, was even more blunt, saying, according to a New York Times article, "In China's thousands of years of civilization, the conflict between humankind and nature has never been as serious as it is today.... The depletion, deterioration and exhaustion of resources and the worsening ecological environment have become bottlenecks and grave impediments to the nation's economic and social development." 102

With such warnings in mind, the Twelfth Five-Year Plan announced a variety of new environmental commitments. ${ }^{103}$ It set a goal of cutting

97. Approval Status of CDM Projects in China (up to April 22, 2009), CLEAN DEV. MECHANISM IN CHINA (Apr. 30, 2009) [hereinafter CEMC, Approval Status], http://cdm.ccchina.gov.cn/english/main.asp?ColumnID=28; China Passes 500 Mark for U.N. Clean Energy Projects, CleAN Dev. MECHANISM IN ChinA (Apr. 1, 2009), http://cdm.ccchina.gov.cn/english/NewsInfo.asp?NewsId=3511. See generally John Copeland Nagle, Discounting China's CDM Dams, 7 LOY. U. CHI. INT'L L. REV. 9 (2009) (summarizing China's reliance on the CDM).

98. See CEMC, Approval Status, supra note 97 (listing all the CDM projects and their project types newly approved as of April 2009).

99. JIABAO, supra note 29 , at 4 .

100. Id. at 24 .

101. Andrew Jacobs, China Issues Warning on Climate and Growth, N.Y. TIMES, Feb. 28, 2011, http://www.nytimes.com/2011/03/01/world/asia/01beijing.html (quoting Wen Jiabao).

102. Id. (quoting an essay written by Zhou and published on the agency's website).

103. Michael Standaert, Leaders Set Environmental, Energy Targets for Five-Year Plan Running Through 2015, WORLD Climate CHANGE REP., Mar. 8, 2011. 
energy intensity by sixteen percent and carbon intensity seventeen percent from 2010 levels by $2015 .^{104}$ It seeks to reduce the emission of traditional pollutants by eight percent to ten percent during the same timeframe. ${ }^{105} \mathrm{It}$ also promises to set emission reductions targets for lead, mercury, chromium, cadmium, and arsenic in certain polluted zones. ${ }^{106}$ The plan sets additional goals for water conservation, forest coverage, and energy conservation. ${ }^{107}$

\section{B. Why China Is Trying to Reduce Its Pollution}

China is pursuing its environmental strategy for several reasons. It wants to be an international leader among nations. It wants to protect the Chinese people from harm and to prevent them from destabilizing the government. It sees an economic opportunity in green jobs. The precise weight that should be afforded each of these reasons may be debated, ${ }^{108}$ but together they have inspired China to take the surprising steps toward reducing pollution outlined in the previous section.

\section{Global Leader}

China aspires to be a leader among the world's nations. That is quite a change from the isolation that it experienced after the Communist revolution of 1949. China began to engage in international affairs when it developed a global market economy in the 1980s. China saw its participation in multilateral treaties as a way by which it could demonstrate its position within the world community. ${ }^{109}$ It joined numerous treaties, including environmental agreements, but it was not a leader in those discussions. For example, China played a minor role in the negotiations that culminated in the Kyoto Protocol in 1997, but then China was one of the

104. Id.

105. JIABAO, supra note 29 , at 13.

106. Id. at 25 ("We will start ... [to] accelerate ... the treatment of heavy metal pollution in key areas ....").

107. See JIABAO, supra note 29 , at 20 ("We will put great effort into water conservancy."); id. ("We will focus on developing more irrigation and water conservation projects."); $i d$. at 24 ("We will strengthen energy conservation."); id. at 25 ("[We will] vigorously carry out afforestation.").

108. ATKINSON, supra note 93, at 67 (citing three reasons for China's support of clean energy technology: mounting pollution, climate change, and "the immense economic opportunities provided by the burgeoning global clean energy industry").

109. See JACQUES, supra note 50 , at 15 ("Since 1978 China has progressively sought to become a fully-fledged member of the international community and has gone to considerable lengths to reassure the West that it is a 'responsible power,' as it likes to describe itself."); $i d$. at 277 (attributing "China's belated embrace of multilateralism" to its growing self-confidence). 
first nations to approve the protocol. ${ }^{110}$ China has since moved to assume a position of global leadership, not just global participation. ${ }^{111}$ Premier Wen Jiabao could thus report in 2011 that "China's international prestige and influence grew significantly." ${ }^{112}$ For China, then, being a world leader in efforts to combat climate change is part of its broader strategy of becoming a world leader on par with the United States or any other nation in the world.

\section{Public Health and Social Stability}

Environmental pollution wreaks a horrible toll on the Chinese people. ${ }^{113}$ China expects that climate change will affect its agriculture and livestock industry, forests and other natural ecosystems, coastal zones, and other sectors. ${ }^{114}$ Even so, "[t] he impacts of climate change ... are fairly remote compared to the Chinese leadership's more immediate concerns about the tremendous levels of soot, smog and other domestic air pollution that are sickening and killing its citizens." $" 115$

The Chinese government is probably more concerned about the social instability that poor environmental conditions may cause. The desire to assure social stability is deeply ingrained in the Chinese psyche from historical experience and motivates much of what the Chinese government does. ${ }^{116}$ Crackdowns on democracy (e.g., in Tiananmen Square in 1989,

110. See Wang, supra note 42, at 95 ("China was the fifth nation to ratify the Kyoto Protocol."); Zang, supra note 27, at 218 (explaining that the State Planning Commission "was not enthusiastic about climate change negotiations in the 1980s and early 1990s" because of "its deeply embedded interests in the energy sector").

111. See Joanna Lewis, The State of U.S.-China Relations on Climate Change: Examining the Bilateral and Multilateral Relationship, 11 CHINA ENV'T SERIES 7, 22-34 (2010/2011) (describing how "China's role ... had shifted" to become a global leader in climate change negotiations); Wang, supra note 42, at 88 ("The role China has played in international negotiations on climate change has changed from that of a reluctant negotiator in the 1990 s to an increasingly active cooperator in the $2000 \mathrm{~s}$."); $i d$. at 93 ("International image concerns prevent China from withdrawing from the evolving international climate change regime. As a rising power, concerns with its international image are at the top of China's international agenda. It has to cautiously avoid any steps that might arouse 'China Threat' issues in the world.").

112. JIABAO, supra note 29 , at 2 .

113. See id. at 1 (describing the impacts of China's pollution).

114. See NDRC, ChinA'S Programme, supra note 84, at 16-19 (describing the impacts of climate change on China).

115. McCubbin, supra note 3, at 212 .

116. See CEC ANNUAL RePORT, supra note 77, at 9 ("The Party, with over 75 million members (roughly 5.7 percent of China's total population), strives to maintain unchallenged rule over a country of more than 1.3 billion people. The Party stakes the legitimacy of its claim to rule China on its ability to provide both stability and prosperity to the Chinese people, and to "unify the country' (tongyi guojia)."); $i d$. at 167 ("The Communist Party and the central government continued to focus on "safeguarding 
following the award of the 2010 Nobel peace prize to a Chinese dissident, and while democracy swept through northern Africa in 2011), religion, and environmentalism are all rooted in this fundamental concern about preserving social stability. Instability in China would present a serious problem for the United States and the rest of the world, too. ${ }^{117}$

Pollution threatens China's stability because Chinese citizens have become increasingly willing to protest poor environmental conditions. ${ }^{118}$ Environmental protests have become commonplace throughout China. "With corruption endemic and little other means of political expression, illegal protest and violence was commonplace and often more effective than using the law. With no democracy, China's government was being held accountable by riot." 119 As one protestor explained, "We would rather be beaten to death than polluted to death."120 The protests threaten China's stability as much as the pollution that motivates them, so the government has responded both by punishing the protestors and by addressing their environmental concerns. ${ }^{121}$

social stability' and strengthened controls over society."); JACQUES, supra note 50, at 78 ("[T]he maintenance of social order and control always being a prime consideration for Chinese rulers."); id. at 82 ("[T]he Chinese attach greatest importance to unity than literally anything else ..."); id. at 211 ("[T]he Chinese have a pathological fear of division and instability ...."); McCubbin, supra note 3, at 215 ("The Chinese leadership's ultimate goal is to maintain the social stability or 'harmonious development' necessary to stay in power ...."); McKibben, supra note 18, at 48 ("The Chinese authorities ... value stability above all else ....").

117. See PAGE \& XIE, supra note 18, at 119 (describing political instability in China as "the greatest danger of all to U.S.-China relations").

118. See CEC ANNUAL REPORT, supra note 77, at 157 ("Chinese citizens are becoming increasingly vocal about concerns over potentially polluting enterprises prior to their construction."); id. at 158 ("Citizens also engaged in demonstrations protesting pollution problems after the fact, following unsuccessful attempts to utilize the petitioning (xinfang) system and other institutionalized channels to resolve their grievances. Specific cases also highlight the possible ill-treatment of citizens, the lack of public involvement in environmental decisionmaking, and the non-transparency of the media."); Lin, supra note 4, at 93 ("In 1995, there were 58,678 petitions filed with the environmental agencies nationwide; in 2006, the number increased to 616,122." (internal citations omitted)); McCubbin, supra note 3, at 214-15 (stating that "China has seen an explosion in the number of citizen protests about environmental issues," citing protests in Xiamen, Shanghai, and Chengdu); Ada Wu, Environmental Mass Incidents in Zhejiang Province, 11 CHINA ENV'T SERIES 135, 135 (2010) (describing the protest that followed an industrial park polluting an eastern Zhejiang province).

119. WATTS, supra note 11, at 110; see also id. at 53 ("Historically, the government's usual response to pollution and disaster was to cover up bad news and arrest the critics.").

120. Wu, supra note 118 , at 135.

121. See CEC ANNUAL REPORT, supra note 77, at 150 ("Citizen environmental complaints continued to increase in number as citizens increasingly voiced concerns about potentially polluting projects. However, channels available to citizens to express environmental concerns and grievances were not always open, contributing to the rise of antipollution demonstrations. Chinese authorities continued to stifle selectively environmental activism and suppress citizens who were involved in or organized collective action to halt perceived environmental harms."); HALPER, supra note 18, at 166 ("[T]he politburo has come to fear environmentalists for much the same reason it fears other groups- 
The massive migration of hundreds of millions of people from rural China to developing urban areas further threatens stability in two ways. First, the migrants often struggle to find work, and the lack of employment opportunities could threaten the stability of the regime. Additionally, the migrants add to China's environmental problems. "As people move off the land and into the sky, they produce less and consume more. In theory, they become socialized and civilized. In practice, they spend more time shopping and eating junk food." $" 122$ Thus Elizabeth Economy reports that "urban residents use $3 \frac{1}{2}$ times more energy than their rural counterparts."

Additionally, the Chinese government has begun to emphasize the threat that climate change poses to its people and land as well. Kenneth Lieberthal told Congress that Chinese "leaders increasingly see climate change itself as a threat to stability." $124 \mathrm{He}$ explained that "just a little under 50 percent of China's GDP [(Gross Domestic Product)] is produced in three coastal areas - the Pearl River Delta, the Yangtze River Delta, and along the Gulf of Bohai. Two of those areas are extraordinarily vulnerable to sealevel rise." ${ }^{\prime 25}$ Chinese leaders "see climate change as a risk to the stability and development of their country," but "this focus on stability also reduces China's willingness to limit carbon usage in ways that might impede economic growth" 126

\section{Economic Advantage}

Last, but not least, China sees climate change as an opportunity to assert its economic supremacy in a new arena. In December 2009, the Breakthrough Institute reported that China, Japan, and South Korea "have already passed the United States in the production of virtually all clean energy technologies, and over the next five years, the governments of these

they have the potential to become an organized social entity directing their bile against the political center. The ruling Communist Party often seems to treat environmental advocates as a bigger threat than pollution itself ...."); WATTS, supra note 11, at 301 ("I met lawyers who were beaten and threatened with closure, writers who were censored, and journalists who were frustrated that their scoops were spiked by editors either because of self-censorship or on the orders of the propaganda department.").

122. WATTS, supra note 11 , at 125 ; see also id. at 128 ("[C]ities tend to distance people from the environment and nurture an unsustainable lifestyle. Metropolises are giant blocks of consumption.").

123. 2009 Senate Hearing, supra note 10, at 13 (statement of Elizabeth Economy, C.V. Starr Senior Fellow and Dir. for Asia Studies, Council on Foreign Relations).

124. Id. at 39 (statement of Kenneth Lieberthal, visiting fellow in foreign policy, Brookings Inst.).

125. Id.

126. Id. at 5 (statement of Sen. Richard Lugar). 
nations will out-invest the United States three-to-one in these sectors."127 According to the report,

China manufactured $8 \mathrm{GW}$ of wind turbines in 2007, and its domestic manufacturing capacity is expected to reach between $12 \mathrm{GW}$ and $20 \mathrm{GW}$ by 2010 . Only five years ago, there was almost no Chinese presence in the wind manufacturing industry. Today, China has at least 70 wind turbine manufacturers, and the top three companies have an annual manufacturing capacity of $4 \mathrm{GW}$. China's domestic wind manufacturers, two of which are ranked in the top ten globally, were poised to start exporting turbines in $2008 .^{128}$

Moreover, the report advised that " $[\mathrm{t}]$ his public investment gap will allow these Asian nations to attract a significant share of private sector investments in clean energy technology, estimated to total in the trillions of dollars over the next decade." $" 129$

This push toward green economic dominance has inspired jealously and outrage. "Earlier this year, while America spent $\$ 80$ billion in green stimulus measures, the largest such investment in our history, China invested $\$ 200$ billion." 130 Even that $\$ 80$ billion was controversial, as Senator Schumer and others objected to the United States government using stimulus funds to pay for wind energy technology imported from China, ${ }^{131}$ Spain, and elsewhere. Then, in December 2010, the United States Trade Representative (USTR) initiated dispute settlement proceedings in the World Trade Organization (WTO) regarding China's wind energy subsidies. ${ }^{132}$ The USTR was responding to a petition filed by a coalition of

127. ATKINSON, supra note 93 , at 3 .

128. Id. at 34. The report also concluded that "China is already a world leader in CCS technology," $i d$. at 36, and it listed Chinese provinces and cities with "aggressive solar subsides" and leading renewable energy technology production centers, $i d$. at 13.

129. Id. at 3. The report explained that China's governmental investments take on added importance because of the "large barriers to the widespread commercialization of clean energy technologies," citing high capital costs, uncertainty, and risk in investing, the absence of necessary transmission infrastructure, intellectual property concerns, little product differentiation, and competition from established energy technologies. $I d$. at 9. Or, as Thomas Friedman explained, "China's leadership is aggressively pushing clean tech because it is a way to make GDP and Green GDP compatible." FRIEDMAN, supra note 1 , at 417.

130. 2009 Senate Hearing, supra note 10, at 3 (statement of Sen. John Kerry).

131. See Press Release, Senator Charles Schumer, Schumer Urges Obama Administration to Block \$450M in Stimulus Funds Sought by Wind Farm Project with Parts Built in China (Nov. 5, 2009) http://schumer.senate.gov/new_website/record.cfm?id=319695\& (opposing the use of stimulus money to build a wind farm in Texas with China-built turbines).

132. Press Release, U.S. Trade Representative, United States Requests WTO Dispute Settlement Consultations on China's Subsidies for Wind Power Equipment Manufacturers (Dec. 22, 2010), 
United States labor unions who assert that China's wind energy subsidies are unfair trade practices prohibited by the General Agreement on Tariffs and Trade. ${ }^{133}$ According to the USTR, "China appears to provide subsidies that are prohibited under WTO rules because the grants awarded under the program seem to be contingent on Chinese wind power equipment manufacturers using parts and components made in China rather than foreign-made parts and components." ${ }^{134}$ The irony, of course, is that China is doing precisely what many American environmentalists have been begging the American government to do as well..$^{135}$ A group of Chinese scholars wrote an open letter condemning the unfair trade claim and expressing concern that the WTO case may undermine China's efforts instead of matching and exceeding them. ${ }^{136}$

\section{The Limits on China's Pollution Control Efforts}

For these three reasons-a push for global leadership, fear of environmental harm and social instability, and a desire for economic gainChina has invested much of its leadership efforts to reduce the country's contribution to and harm from climate change. But "few within China's elite discuss climate change with a sense of urgency; the priorities remain continued rapid economic growth and social stability." ${ }^{137}$ China's efforts to reduce pollution and to mitigate climate change confront three significant obstacles: the unquestioned priority of rapid economic development, the

available at http://www.ustr.gov/about-us/press-office/press-releases/2010/december/united-statesrequests-wto-dispute-settlement-con.

133. Id.

134. Id.; see also Daniel Pruzin, U.S. Initiates WTO Proceedings against Chinese Subsidies for Wind Power Goods, 34 INT'L ENV'T REP. 59, 59-60 (2011) (explaining the United State's dispute settlement proceedings at the WTO challenging China's subsidies to Chinese producers of wind power equipment).

135. See, e.g., ATKINSON, supra note 93, at 11 (stating the U.S. government must "significantly increase investment in clean energy innovation by making a sustained commitment to research, development, and demonstration"); see also Letter from Wang Hui et al. to Todd Stern, U.S. Special Envoy on Climate Change, A Challenge for the U.S. to Match China's Efforts to Address Climate Change at 2-3, available at http://www.eu-china.net/web/cms/upload/pdf/materialien/ Chinese_academics_2010_open_letter_to_US_climate_change_10-10-06.pdf ("It is ironic indeed that some actors in the United States simultaneously attack China for increasing emissions and also for the measures taken to switch from carbon-intensive fossil fuels to renewable clean energy.").

136. Letter from Hui et al., supra note 135, at 2.

137. 2009 Senate Hearing, supra note 10, at 50 (statement of Elizabeth Economy, C.V. Starr Senior Fellow and Dir. for Asia Studies, Council on Foreign Relations); see also WATTS, supra note 11, at 216 ("I have found the debate about global warming to be less urgent than in developed nations .... Many expressed a feeling of injustice because China was often blamed for being the world's biggest emitter of greenhouse gas."). 
overwhelming dependence on coal, and the failure to actually implement the environmental laws that it has enacted.

\section{Development Remains the Overriding Priority}

Economic development is the highest priority for the Chinese government. Anything that would limit China's development provokes suspicion. Some Chinese believe that the international pressure on China to reduce emissions is really aimed at reducing China's economic competitiveness. ${ }^{138}$ Thus, China has been unwilling to adopt stringent domestic pollution control measures such as a cap-and-trade system. Nor is China willing to change its consumption patterns. It insists upon a "pollute first, clear up later' outlook on development." ${ }^{.139}$

The focus on development means that economic decisions will affect the amount of pollution more than government regulation. ${ }^{140}$ As one writer put it, "Pollution was yesterday's priority. Climate change is tomorrow's. Both are symptoms of a bigger more immediate malaise: the unsustainable consumption pioneered by advanced, wealthy democracies and now increasingly replicated by rich citizens of developing nations like China." ${ }^{\prime 141}$ And the preoccupation with economic development accounts for the possibility that it will benefit more from continued emissions than from reducing them. ${ }^{142}$

\section{China Remains Dependent on Coal}

The environmental impact of China's economic development is exacerbated by China's continuing addiction to coal. Most Americans fail to realize that "coal mines are as much a part of China's civilization as paddy

138. See 2009 Senate Hearing, supra note 10, at 41 (statement of Kenneth Lieberthal, Visiting Fellow in Foreign Policy, Brookings Inst.); FRIEDMAN, supra note 1, at 399 ("[G]lobal warming is perceived by more than a few Chinese as a 'conspiracy' concocted by the West to slow China's growth."); Wang, supra note 42, at 98 (advising that some Chinese government officials, intergovernmental organization officials, nongovernmental organization officials, and scholars believe that the international pressure on China to agree to a binding emissions reduction "is a plot by some western countries to curtail China's rapid development").

139. WATTS, supra note 11 , at 16.

140. 2009 Senate Hearing, supra note 10 at 5 (statement of Sen. Richard Lugar) ("[T]he fundamental trends in China toward industrialization, urbanization, higher standards of living will have far more impact on the growth of emissions than government policy.").

141. WATTS, supra note 11 , at 324.

142. See Sunstein, supra note 38 , at 1677 ("[U]nilateral [emissions] reductions would impose significant costs and by themselves produce no significant benefits."). 
fields." ${ }^{143}$ China's air pollution and greenhouse gas emissions are increasing so rapidly because coal fuels most of the country's rapid economic growth. ${ }^{144}$ The statistics are sobering. China is the world's leading producer of coal, mining nearly triple the amount of the United States. ${ }^{145}$ China is also the second leading importer of coal. ${ }^{146}$ Sixty-nine percent of China's primary energy and eighty percent of its electricity generation comes from coal. ${ }^{147}$ "China and India harbor around one-quarter of the world's coal reserves, and are deploying them rapidly to fire electric power plants."148 Additionally "China is currently installing 1000 megawatts (MW) of coal power generation each week." 149

The environmental consequences of China's reliance on coal are seen in the country's pollution and greenhouse gas emissions. The burning of coal explains why China hosts so many of the world's most polluted cities, ${ }^{150}$ but coal also results in substantial pollution in rural areas. Bryan Tilt lists five factors for why coal is so ubiquitous and so harmful in China's rural areas: (1) coal is abundant, (2) government price regulations make coal cheap, (3) rural facilities lack the capital to invest in pollution control equipment, (4) energy efficiency is poor in rural facilities, and (5) rural facilities are less likely to be subjected to regulatory scrutiny. ${ }^{151}$ Throughout China, the abundance of coal and the costliness of its alternatives conspire to make China dependent on coal for its economic development during the upcoming years.

143. See WATTS, supra note 11 , at 180 ("[D]espite its reputation as an agricultural civilization, for most of the last 2000 years China has been by far the biggest producer of coal and iron in the world, a status lost only temporarily in the early nineteenth century when Britain began industrializing."); see also Shannon R. Brown, Technology, Economics, and Politics in the Modernization of China's CoalMining Industry, 1850-1895, 18 EXPLORATIONS IN ECON. HIST. 60, 80 (1981) (citing China's prohibition on foreigners developing coal mines and the effective prohibition on private development as the reasons for China's failure to keep pace with coal development during the nineteenth century); Huaichuan Rui, Development, Transition and Globalization in China's Coal Industry, 36 DEV. \& CHANGE 691, 692 (2005) (exploring the reasons that "the state has been so ineffective in delivering policies and regulations in the coal industry").

144. See 2009 Senate Hearing, supra note 10, at 6 (statement of Kenneth Lieberthal, Visiting Fellow in Foreign Policy, Brookings Inst.).

145. See IEA, STATISTICS, supra note 44, at 15 (listing countries that produce coal and the amount each country produces).

146. See id. (listing Japan as the leading importer).

147. See Lewis, supra note 111 , at 9.

148. Steven Ferrey, The Missing International Link for Carbon Control, 22 ELECTRICITY J. 17, $19,(2009)$.

149. Steven Ferrey, The Failure of International Global Warming Regulation to Promote Needed Renewable Energy, 37 B.C. ENVTL. AFF. L. REV. 67, 88 (2010).

150. See supra note 1 (providing varying assessments of the number of worst-polluting cities located in China).

151. See TiLT, supra note 15 , at 69 . 


\section{The Inability to Actually Implement Environmental Regulations}

In 2009, Senator John Kerry remarked that "it's time to retire, once and for all, the old outdated stereotype that China doesn't care at all and China won't act. They do care, and they are acting." 152 Kerry added that "what I heard was, in fact, very encouraging. Now, words are words."153 The gap between words and actions looms large in China. As one local official explained, Communist Party leaders "speak sweet words, but continue to do bad things." 154

Numerous scholars have observed that China struggles to enforce the environmental regulations that the central government adopts. China's top environmental lawyer estimates that only ten percent of the country's environmental laws are actually enforced. ${ }^{155}$ Elizabeth Economy testified to the United States Senate in 2009 that

$[\mathrm{t}]$ here are few incentives within China's political system to enforce environment-related laws and regulations. Even when Chinese factories and powerplants have pollutioncontrol equipment, they often don't use it, or they may use it only when the inspectors appear. There is very poor data collection, transmission, and transparency at every level of the Chinese system, and the incentive is often to hid negative information. We saw this in the runup to the Olympics, when the Beijing city government simply moved the air-pollution monitoring equipment from one part of the city to another in order to put forth better air-quality statistics that were actually there. ${ }^{156}$

And consider this explanation of China's poor environmental enforcement offered by Daniel Abebe and Jonathan S. Masur:

[A]s a result of its growth-driven delegation of power, the [Chinese Communist Party] CCP suffers from a surprising (for such a centralized government) erosion of state

152. 2009 Senate Hearing, supra note 10, at 3 (statement of Sen. John Kerry); see also id. at 8 (statement of Kenneth Lieberthal, Visiting Fellow in Foreign Policy, Brookings Inst.) (describing China's climate change policies as "very impressive" and "constantly growing").

153. Id. at 2 (statement of Sen. John Kerry).

154. Mao's Footprint, MELTDOwN IN TIBET, http://www.meltdownintibet.com/f_redgreen.htm (last visited Apr. 16, 2011) (incorrectly attributing this phrase to WATTS, supra note 11, at 68).

155. 2009 Senate Hearing, supra note 10, at 18 (statement of Elizabeth Economy, C.V. Starr Senior Fellow \& Dir. for Asia Studies, Council on Foreign Relations) (citing the claim of Wang Canfa).

156. Id. at 12-13 (statement of Elizabeth Economy, C.V. Starr Senior Fellow \& Dir. for Asia Studies, Council on Foreign Relations). 
capacity: the provinces often ignore the central government's directives, frequently without meaningful consequences. The political structure of the CCP and the institutional structure of China's government are sometimes overlapping or redundant and, in many places, lack effective vertical or horizontal accountability. The environmental regulatory agencies are often subordinate to the very agencies they are intended to regulate. Provincelevel CCP officials are often evaluated (both locally and in Beijing) by their ability to produce high levels of economic growth, not their commitment to environmental protection. Although the CCP has recently tried to recentralize power and rationalize the governance structure, the center's capacity to enforce environmental regulations on the provinces is much weaker than in a typical industrialized state. The existing structural relationship between the provinces and Beijing often results in a chronic inability on the part of the CCP to provide public goods like environmental protection, an inability it will not be able to reverse without incurring substantial costs. ${ }^{157}$

This disconnect between the central government's decrees and the local government's disinterest surprises many Americans. The popular image of

157. Ababe \& Masur, supra note 49, at 330; see also 2009 Senate Hearing, supra note 10, at 5 (statement of Sen. Richard Lugar) ("[I]t remains unclear whether China will develop the capacity to effectively implement its new regulations, or even whether it can accurately measure their impact."); CEC ANNUAL REPORT, supra note 77, at 154 ("Selective official enforcement and enterprise noncompliance with China's environmental impact assessment regulations continue to blunt their effectiveness .... Compliance problems in less developed areas of China are exacerbated because polluting enterprises with prohibited, antiquated equipment have been known to move to poorer areas within provinces or across provinces after being shut down in more developed areas."); JACQUES, supra note 50, at 206 ("The provinces and cities accept Beijing's word, while often choosing to ignore it, with central government fully aware of this. Although China has a unitary structure of government, in reality its modus operandi is more that of a de facto federal system."); $i d$. at 173 ("[O]n paper China already has some of the most advanced laws in the world on renewable energy, clean production, environmental impact assessment and pollution control, though these still remain widely ignored in practice. The government continues to resist the idea that environmental considerations should detract from the priority of rapid economic growth, but there is, nonetheless, widespread recognition of their urgency at the highest levels of the Chinese leadership."); TILT, supra note 15, at 112-20 (analyzing the effort to enforce environmental regulations in Futian Township in Sichuan Province); WATTS, supra note 11, at 113 ("Efforts to make polluters pay or to account for environmental costs faltered because of weak governance."); McCubbin, supra note 3, at 202 ("[U]nless remedied, the substantial weaknesses in China's rule of law will prevent effective implementation of its climate change commitments."); $i d$. at 232 ("Unless China makes substantial changes in the nation's ability to enforce its environmental requirements, the success of any Chinese intentions to reduce greenhouse gases could well be in jeopardy."). 
China's government is that it controls everything within the country and that it can do whatever it wants.

\section{SOLVING THE THREe PROBLEMS}

How much should China pollute? The answer to that question must address the problems that China's pollution presents for its own citizens and governance, for the willingness of the United States to respond to climate change more aggressively, and for the global community's efforts to address climate change. The answer must also reconcile China's rhetoric (which simultaneously rejects an international obligation to reduce emissions while championing efforts to do so) and China's actions (which, again, simultaneously includes many impressive steps toward developing renewable energy but which also includes a repeated failure to actually implement environmental regulations).

This part sketches three ways to confront the problems that China's pollution causes. First, this part argues that China should reduce its pollution to prevent it from harming its own people or those in other places. Second, this part contends that China should be encouraged to achieve the rule of law in environmental policy, rather than other nations imitating China's environmental governance structure. Third, this part calls on the United States to pursue more bilateral efforts to work with China on these issues, even when global agreement on a comprehensive climate change treaty remains elusive.

\section{A. China's Pollution Should Not Harm Itself or Others}

The government should prevent pollution from harming human health. That is the premise of American pollution laws. ${ }^{158}$ It is also evident in the evolving international environmental law's understanding of pollution. ${ }^{159}$ The concept of sustainable development also supports the claim that economic development should not result in pollution that harms public health. As discussed above, China's commitment to sustainable

158. See supra Part I.B.1 (discussing American environmental statutes that emphasize the protection of public health).

159. See Dinah Shelton, Human Rights and the Environment: What Specific Environmental Rights Have Been Recognized?, 35 DENV. J. INT'L L. \& POL'Y 129, 140-51 (2006) (analyzing the right to life and the right to health). 
development means that China should modify its economic development to avoid the massive pollution that has come to characterize the nation. ${ }^{160}$

\section{B. Achieving the Rule of Law in China}

Coincidentally or not, in 2009 the United States Senate Foreign Relations committee chose the anniversary of the Tiananmen Square massacre to hold a hearing on China's climate change policies. Senator Kerry nodded toward the significance of that date when he "urge[d] the Chinese to unleash the dynamism of the Chinese people through further political liberalization and strengthening the rule of law and making government fully accountable to the people." ${ }^{, 161}$ Much has been done during the past thirty years to introduce the rule of law to China, but there are still huge obstacles. Chinese environmental lawyers are probably as likely to be jailed for their efforts as they are to succeed in obtaining real relief for individuals harmed by pollution.

The government has been particularly unwilling to be "fully accountable to the people," as Senator Kerry put it. ${ }^{162}$ It is not even clear that the people care if the government is accountable to them in the sense that is familiar to those of us in the United States. As Jacques explains, China has developed "a new kind of social compact between the Party and the people: the task of the Party is to govern, while the people are left free to get on with the business of transforming their living standards. Far from interesting themselves in politics, people have increasingly retreated into a private world of consumption." $163 \mathrm{He}$ adds that "the idea of popular sovereignty ... remains largely absent in China." 164

Of course, popular sovereignty means that sometimes the people make decisions that do not seem to make sense and that worsen environmental problems rather than solve them. That phenomenon has led some American writers to envy China's method of governance. Thomas Friedman, for example, entitled one chapter in his best-selling book "China for a Day (but

160. See supra Part II.C (discussing the obstacles to China's efforts to reduce pollution and to mitigate climate change).

161. 2009 Senate Hearing, supra note 10, at 4 (statement of Sen. John Kerry).

162. Id.

163. JACQUES, supra note 50, at 224; see also id. at 103 (describing China's "new kind of political governance, namely the developmental state, whose popular legitimacy rests not on democratic elections but the ability of the state to deliver continued economic growth").

164. Id. at 209. Jacques further explained that "[u]nlike in the Western tradition, the role of government has no boundaries; rather like a parent, with which it is often compared, there are no limits to its authority. Paternalism is regarded as a desirable and necessary characteristic of government." Id. at 199. Moreover, "[t]he absence of a civil society and an autonomous public realm in Communist China is not a new phenomenon: China has never had either." Id. at 96. 
Not for Two)" ${ }^{9165}$ Friedman explained that while he generally regards China's system of government as inferior to the American system, he finds one (and only one) aspect of China's government appealing:

That is the ability of China's current generation of leaders-if they want-to cut through all their legacy industries, all the pleading special interests, all the bureaucratic obstacles, all the worries of voter backlash, and simply order top-down the sweeping changes in prices, regulations, standards, education, and infrastructure that reflect China's long-term strategic national interestschanges that would normally take Western democracies years or decades to debate and implement. ${ }^{166}$

Once the government issued those orders, Friedman adds, then "the next day we would be able to enjoy the best part of our democracy (the power of our civil society to make government rules stick and the power of our markets to take advantage of them)." ${ }^{\prime 167}$ Nor is Friedman alone in embracing China's system, and some observers do not include his one day caveat. ${ }^{168}$ These writers often acknowledge the harms imposed by China's authoritarian rule, but, with respect to climate change, there is a sense that the ends may in fact justify the means. Hence the characterization of "authoritarian chic." 169

There are many arguments for representative democracy instead of authoritarian governance, and this article need not rehash them here. It should be remembered, though, that the praise of China's approach to

165. FRIEDMAN, supra note 1 , at 429 .

166. Id. at 430 .

167. Id. at 432 .

168. See HALPER, supra note 18 , at x ("China's market-authoritarian model provides rapid growth, stability, and the promise of a better life for its citizens." And, "China's governing model is more appealing to the developing world and some of the middle-sized powers than America's marketdemocratic model."); JACQUES, supra note 50, at 136 (arguing that paternalistic leadership provides "much more latitude to change direction and policies" and the ability "to take a longer-term attitude towards society and its needs"); WATTS, supra note 11, at 271 ("Prominent foreign commentators began to laud the virtues of authoritarianism .... China's ability to get things done for the environment compared favorably against wishy-washy Western democracies that had to buy off voters with ever greater promises of consumption .... It is perhaps a measure of the environmental crisis facing humanity and the gains made by China that such an influential liberal was willing to consider dictatorship as, at least, a partial solution."); Debra Kahn, "Too Much Democracy" Hamstrings U.S. Industry - Chinese, U.S. Execs, GREENWIRE, Mar. 3, 2011 (quoting Zhengrong Shi, head of a large solar energy manufacturer, as saying that "[s]ometimes I feel perhaps there is too much democracy here. There's [sic] no decisions.").

169. Ying Ma, China's View of Climate Change, 161 POL'Y REV., June 1, 2010, http://www.hoover.org/publications/policy-review/article/5302. 
environmental regulation ignores what actually happens in China. As Watts explains:

Weak governance and dire pollution go hand in hand. China's political system is neither dictatorship nor democracy. For the environment, it contains the worst elements of both. At the top, the state lacks the authority to impose pollution regulations and wildlife conservation laws, while at the bottom citizens lack the democratic tools of a free press, independent courts and elections to defend their land, air and water. The gap in between is filled by local governments, township enterprises, migrant workers and foreign corporations, many of which are focused on economic growth at the expense of all else. The result is neither red nor green; it is black or gray. ${ }^{170}$

The government's prosecution of environmental activists, and its desire to maintain control above all else, hinders any serious attempt to control the massive amounts of pollution that have produced an environmental crisis in China. ${ }^{171}$ Those actions also threaten the very stability that China craves. ${ }^{172}$

\section{The United States Should Pursue More Bilateral Agreements with China}

Most nations blamed the United States and China for the failure to agree to a new international climate change treaty in Copenhagen in December 2009. In 2010, a group of Chinese individuals and organizations wrote to the United States special envoy on climate change, Todd Stern, to "call upon the US to stop drawing attention away from its own domestic failures by trying to divert attention to China. The US must at least match China's efforts to address climate change, instead of continuing to use

170. WATTS, supra note 11 , at 88 .

171. See CEC ANNUAL REPORT, supra note 77, at 9-10 ("The rule of law, if implemented faithfully and fairly, should benefit not just those the Party favors. Some of China's leaders, therefore, regard implementation of the rule of law as potentially diminishing the capacity of the Party to maintain control."). Elizabeth Economy agrees that "there is a lack of political will in Beijing to make the necessary fundamental changes to tackle the climate change challenge effectively, such as the rule of law, transparency, and official accountability." 2009 Senate Hearing, supra note 10, at 50 (statement of Elizabeth Economy, C.V. Starr Senior Fellow \& Dir. for Asia Studies, Council on Foreign Relations).

172. See CEC ANNUAL REPORT, supra note 77, at 2 ("Stability in China is in the national interest of the United States. The Chinese government's full and firm commitment to openness, transparency, the rule of law, and the protection of human rights, including worker rights, marks a stability-preserving path forward for China. Anything less than the government's full and firm commitment to protect and enforce these rights undermines stability in China."). 
China as an excuse for inaction." ${ }^{173}$ More pointedly, the writers insisted that "[i]t is time for the United States to stop using China as an excuse for inaction, and to move forward with whatever honest efforts it can come up with." $" 174$

Such efforts are hindered, though, by the widespread belief in the United States that China will not reciprocate by taking actions that are contrary to its own self interest. Whether or not that concern is well founded, it suggests that China and the United States can best address their common pollution and climate change problems by working together. There are three ways in which they can do so: collaborating, competing, and committing.

\section{Collaboration}

There are already countless U.S.-China partnerships related to environmental issues, ${ }^{175}$ and there could be even more. They should make green development economically advantageous for both nations. The United States should help China-and press China - to overcome its inability to actually implement its environmental policies. Elizabeth Economy has listed "building capacity and transparency, official accountability, and the rule of law" as the most important areas for cooperation between China and the United States. ${ }^{176}$ Economy adds that the United States should "help transform China's urbanization process" by sharing its expertise in transportation, energy efficiency, and land

173. Hui, supra note 135 , at 1 .

174. Id. at 3 .

175. See COMM. ON U.S.-ChINA COOPERATION, supra note 95, at 175-89 (describing U.S.China cooperation on wind energy); U.S. DEP'T OF ENERGY, U.S.-ChINA ClEAN ENERGY COOPERATION: A PROGRESS REPORT BY THE U.S. DEPARTMENT OF ENERGY (2011), available at $\mathrm{http} / / /$ www.pi.energy.gov/documents/USChinaCleanEnergy.PDF (reporting on the progress of seven joint initiatives begun in November 2009: (1) U.S.-China Clean Energy Research Center, (2) Electric Vehicles Initiative, (3) Energy Efficiency Action Plan, (4) Renewable Energy Partnership, (5) 21st Century Coal, (6) Shale Gas Resource Initiative, and (7) and Energy Cooperation Program); Lewis, supra note 111, at 26-34 (providing a "Timeline of US-China Clean Energy Climate Change Cooperation"); Ari Natter, Chinese, American Officials Stress Cooperation, Announce Clean Energy Deals, World Climate Change ReP., Jan. 18, 2011 ("[Thirteen] companies from the two countries were entering into business deals related to clean energy technologies ...."); Stephanie B. Ohshita \& Lynn K. Price, Lessons for Industrial Energy Efficiency Cooperation with China, 11 CHINA ENV'T. SERIES 49 (2010/11) (discussing the numerous partnerships between China and the U.S. and other nations).

176. 2009 Senate Hearing, supra note 10, at 14 (statement of Elizabeth Economy, C.V. Starr Senior Fellow \& Dir. for Asia Studies, Council on Foreign Relations). 
development. ${ }^{177}$ The United States should also recognize that many young urban Chinese people are looking "for something more than postmodern, globalized materialism." ${ }^{\prime 17}$ Clean energy collaboration may depend on far more than the technical specifications of energy production.

\section{Competition}

President Obama emphasized competition with China regarding clean energy development in his 2011 State of the Union Address. ${ }^{179}$ Thomas Friedman believes that "the greatest thing that the United States could do today for itself, for China, and the world is to publicly state its intention to 'outgreen China' - to let the Chinese know every day in every way that we are going to try to clean their clock in the next great global industry: clean power." "180 But Congress sees the problem differently. As Senator Sanders asked, "Is it fair to ask American manufacturers to compete against companies in China where there are virtually no environmental regulations and in a country which is becoming one of the most polluted countries in the world?"181 Many Americans believe that China is engaged in unfair competition with the United States, which can only be remedied by rewriting the rules in a way that the Chinese themselves will not accept. ${ }^{182}$ President Obama has argued that successful American competition with China also requires lots of government spending to overcome the economic

177. Id. at 19 (statement of Elizabeth Economy, C.V. Starr Senior Fellow \& Dir. for Asia Studies, Council on Foreign Relations); see also id. at 13 (citing the need for "capacity-building for the enforcement of energy-efficient building codes" because "[h]alf of all new building space in the world is going up in China").

178. WATTS, supra note 11 , at 301.

179. See President Barack Obama, State of the Union Address (Jan. 25, 2001) [hereinafter State of the Union] ("The first step in winning the future is encouraging American innovation. ... We'll invest in ... clean energy technology - an investment that will strengthen our security, protect our planet, and create countless new jobs for our people. . . O Our infrastructure used to be the best, but our lead has slipped. ... China is building faster trains and newer airports."); see also President Barack Obama, Weekly Address: We Can Out Compete Any Other Nation, WHiTE House (Jan. 22, 2011), http://www.whitehouse.gov/the-press-office/2011/01/22/weekly-address-president-obama-we-can-outcompete-any-other-nation.

180. FRIEDMAN, supra note 1 , at 422.

181. 149 CONG. REC. 10,065 (2003).

182. See, e.g., Press Release, BBC Press Office, Global Poll Reveals Rising Concern about China's Increasing Power (Mar. 28, 2011), available at http://www.bbc.co.uk/pressoffice/pressreleases/stories/2011/03_march/28/china.shtml ("[W]orries about China's economic growth are related to perceptions that China's trade practices with other countries are unfair. Overall, more than one-third of those polled (35\%) rated China's trade practices as unfair . ..."). 
obstacles to new, greener energy technologies. ${ }^{183}$ Again, though, Congress is unlikely to approve the amount of massive government spending that many say is necessary to empower American industries to compete with China. Proposals for increased government spending on clean energy technologies are caught up in the broader debate about the role of the government in technological innovation and the appropriate amount of government expenditures. And even as it has promoted more government spending, the Obama Administration claims that some of China's government subsidies for its own industries are illegal under international trade rules. ${ }^{184}$ These two barriers - the governing rules and the necessary funds - must be overcome before competition between China and the United States yields the presumed benefits of clean energy development. The fact that China and the United States must work together to eliminate those barriers has prompted some observers to call for "cooperative competition" between the two countries. ${ }^{185}$ Meanwhile, China is widely regarded as winning the clean energy race with the United States, and one member of Congress has even described China's wind turbines as "economic missiles pointed at the heart of the United States economy." 186

\section{Commitment}

Efforts to commit the United States to binding greenhouse gas reductions at the global level (via the Kyoto Protocol or a new international agreement) or at the domestic level (via new federal comprehensive climate change legislation) have failed spectacularly. Yet, as Senator from Illinois, President Obama once insisted that:

183. See State of the Union, supra note 179 ("We'll invest in . . clean energy technology-an investment that will strengthen our security, protect our planet, and create countless new jobs for people.").

184. See supra notes 130-136 and accompanying text (discussing objections to use of stimulus funds on wind energy technology imported from China and discussing the U.S. Trade Representative's proceeding against China regarding wind energy subsidies).

185. See COMM. ON U.S.-ChInA COOPERATION, supra note 95, at 21 (discussing the advantages to U.S.-China cooperative competition); Lewis, supra note 111, at 17.

186. The Global Clean Energy Race: Hearing Before the H. Select Comm. on Energy Independence \& Global Warming, 111th Cong. 1 (2010) (statement of Rep. Edward J. Markey, Chairman, H. Select Comm. on Energy Independence \& Global Warming), available at http://globalwarming.house.gov/files/HRG/FullTranscripts/111-19_2010-09-22.pdf; see also id. at 17 (statement of Ravi Viswanathan) ("Though the U.S. continues to be the home of the world's best clean energy innovation, the U.S. has lost its leadership to China, Japan, and Germany in clean energy manufacturing deployment and is challenged and threatened by emerging economies such as India, South Korea, Malaysia, and the Philippines."). 
[I]t is impossible for us to encourage countries such as China and India to do the right thing if we, with a much higher standard of living and having already developed ourselves so we are the energy glutton of the world, are unwilling to make these modest steps to decrease the amount of emissions that affects the atmosphere overall. ${ }^{187}$

Thus the dilemma described earlier: the United States will not commit to reducing its pollution unless China does the same, but China will not make any binding international commitments. Perhaps the way out of that dilemma is for the United States and China to enter into bilateral agreements respecting climate change. Such agreements could go beyond the collaboration that already characterizes existing agreements. The United States and China may have greater success than the global community as a whole in identifying an agreement that is acceptable to them. That is the premise of a growing number of studies that have sought alternatives to the global process that failed to achieve an agreement in Copenhagen in $2010 .{ }^{188}$ The goal would be to find areas of agreement between the two countries where they could commit to actions that they would be unwilling to take alone.

\section{CONCLUSION}

China's pollution harms China, the United States, and the whole world. China realizes that now, but it clings to a pace of development that prevents the actions necessary to avoid the toll that such pollution takes on the lives of millions of Chinese people, and even people living elsewhere as well. China must reduce its pollution so its own people do not suffer, even as China continues the economic development that has helped so many people in China. Meanwhile, many global environmental activists see the United States as the obstacle to global progress on climate change. "The reality," proclaimed Senator Kerry, "is that a robust American partnership with China will do more than anything else to ensure a successful global response to the urgent threat of climate change." 189

187. 151 CONG. REC. S13,635 (daily ed. June 22, 2005) (statement of Sen. Barack Obama).

188. See, e.g., AU, supra note 21, at 5-6 (emphasizing the value of "an entrepreneurial, bottomup process" that is embraced by the United States and China).

189. 2009 Senate Hearing, supra note 10, at 1 (statement of Sen. John Kerry). 